\title{
Effects of Phosphorus Fertilizer Rates and Its Placement Methods on Residual Soil Phosphorus, Yield, and Phosphorus Uptake of Maize: At Bedele District, Ethiopia
}

\author{
Bati Dube ${ }^{1, *}$, Achalu Chimdi ${ }^{2, *}$ \\ ${ }^{1}$ Oromia Agricultural Research Institute, Bedele Agricultural Research Center, Bedele, Ethiopia \\ ${ }^{2}$ Department of Natural Resources Management, Ambo University, Ambo, Ethiopia \\ Email address: \\ duberoba16@gmail.com (B. Dube), achaluchimdi@gmail.com (A. Chimdi) \\ ${ }^{*}$ Corresponding author
}

To cite this article:

Bati Dube, Achalu Chimdi. Effects of Phosphorus Fertilizer Rates and Its Placement Methods on Residual Soil Phosphorus, Yield, and Phosphorus Uptake of Maize: At Bedele District, Ethiopia. American Journal of Agriculture and Forestry. Vol. 9, No. 5, 2021 , pp. 319-333. doi: 10.11648/j.ajaf.20210905.16

Received: September 29, 2021; Accepted: October 21, 2021; Published: October 30, 2021

\begin{abstract}
In spitefulness of the increase in land areas under maize production, yield is still low due to declining soil fertility because of un-appropriate use of fertilizer rates and placement methods. Therefore this study was conducted to determine $\mathrm{P}$ fertilization rates and the relative effectiveness of different placement methods on the yield, $\mathrm{P}$ uptake of maize and concentration of $\mathrm{P}$ in the soil. The experiment was carried out at Bedele district. Four level of $\mathrm{P}$ fertilizer $(0,23,46$ and 69 $\mathrm{P}_{2} \mathrm{O}_{5}$ kgha $^{-1}$ ) and three placement methods of $\mathrm{P}$ application (broadcasting $\mathrm{P}$ and seeds, surface banding $\mathrm{P}$ to the side of the seeds, and deep band P fertilizer below the seeds) were implemented as treatments with three replications in randomized complete block design. Dry biomass, grain yield, straw yield, harvest index, residual soil P, and total P in grain were highly significantly $(\mathrm{P}<0.01)$ influenced by effect of $\mathrm{P}$ fertilizer rates and placement methods. Total $\mathrm{P}$ in the soil significantly $(\mathrm{P}<0.05)$ influenced by placement methods. Mean plant height, total $\mathrm{N}$ in the grain and total $\mathrm{N}$ in the stalks highly significant $(\mathrm{P}<0.01)$ influenced by effect of $\mathrm{P}$ fertilizer rates and its placement methods. The mean days to maturity highly significantly $(\mathrm{P}<0.01)$ influenced only by $\mathrm{P}$ fertilizer rates. The highest grain yield $\left(78.40 \mathrm{qt} \mathrm{ha}^{-1}\right)$ and biomass yield $\left(142.11 \mathrm{qt} \mathrm{ha}^{-1}\right)$ were noted from surface banding of $\mathrm{P}$ fertilizer to the sides of the seeds at application of $69 \mathrm{P}_{2} \mathrm{O}_{5} \mathrm{~kg} /$ ha respectively when compared with the no $\mathrm{P}_{2} \mathrm{O}_{5}$ application. However, $\mathrm{P}$ and $\mathrm{N}$ uptakes by Maize ranged from $0.84 \%$ with no $\mathrm{P}_{2} \mathrm{O}_{5}$ to $1.32 \%$ at the rate of $69 \mathrm{~kg}_{2} \mathrm{O}_{5}$ ha $^{-1}$ and $0.656 \%$ with no $\mathrm{P}_{2} \mathrm{O}_{5}$ to $1.04 \%$ at rate of $69 \mathrm{~kg} \mathrm{P}_{2} \mathrm{O}_{5}$ ha $^{-1}$, respectively. Also, the residual soil $\mathrm{P}$ after harvest of the maize ranged from 1.312 with no $\mathrm{P}_{2} \mathrm{O}_{5}$ to $11.79 \mathrm{ppm}$ was recorded at application of $69 \mathrm{~kg} \mathrm{P}_{2} \mathrm{O}_{5} \mathrm{ha}^{-1}$. Therefore, using surface banding $\mathrm{P}$ fertilizer to the sides of the seeds with $69 \mathrm{~kg} \mathrm{P}_{2} \mathrm{O}_{5} \mathrm{ha}^{-1}$ to increase the production of maize over increase the efficiency of $\mathrm{P}$ uptake.
\end{abstract}

Keywords: Maize BH661, Recommended Fertilizer Rate, Urea, Band Application, Soil P, Nutrient Uptake

\section{Introduction}

Ethiopia's economy is dependent on agriculture, accounts for 40 percent of the gross domestic product (GDP), 80 percent of exports, and an estimated 75 percent of the country's workforce [1]. In spite of the increase in land areas under maize production, yield is still low. Some of the main causes of low maize yield are declining soil fertility. Low soil fertility is recognized as a constraint to increased food production and farm incomes in many parts of Sub-Saharan
African [2]. Ethiopia is one of the Sub Saharan countries with highest rates of nutrient depletion due to lack of adequate synthetic fertilizer input, limited return of organic residues and manure, high biomass removal from farm lands, high soil erosion rate and leaching loss of nutrient elements [3]. Therefore, maize requires adequate supply of nutrients particularly $\mathrm{N}, \mathrm{P}$ and $\mathrm{K}$ for good growth and high yield. $\mathrm{N}$ and $\mathrm{P}$ are very essential for good vegetative growth and seed 
development in maize production [4], it is a heavy feeder with high $\mathrm{N}$ requirement. Its demand for $\mathrm{N}$ is also high and it is sensitive to a low phosphate supply particularly at early stages of growth [5].

$\mathrm{P}$ is essential to many important plant processes such as energy storage and transfer. $\mathrm{P}$ has a unique relationship with soil constituents, often becoming unavailable for plant utilization; making P fertilization decisions an important part of nutrient management [6]. P, the second most widely limiting nutrient in soil after $\mathrm{N}$ [7], it is also, a critical macronutrient for plant growth and in tropical agro-ecosystems soil, $\mathrm{P}$ deficiency is a major limitation to crop production [8]. Generally, diammonium phosphate (DAP), monoammonium phosphate (MAP) and triple superphosphate (TSP) account for half of phosphate-based fertilizer applications. International trade in processed phosphates (DAP, NPS, MAP and TSP) would expand from 35Megatone in 2018 based on preliminary estimates by $7 \%$ during the next five years, to fluctuate between 37 and 38 Megatone products in 2023 [9].

Although, maize (Zea mays L.) is the most widely cultivated cereal crop in terms of area coverage (16\%) and production $(26 \%)$ with about 6.5 million tonne of production in Ethiopia [10], it is also the major staple food crop and source of cash in the country and although one of the most productive crops in Ethiopia, it cannot play a significant role in ensuring food security because of various factors [11]. However,[12] identified, "arbitrary ways of fertilizer application in Ethiopia added to the vagrancy of nature has contributed to its use inefficiency". It is generally assumed that fertilizer placement affects the use efficiency of fertilizer nutrients, level of salt toxicity as well as conveniences of crop management practices.

Based on the various concerns of $\mathrm{P}$ fertilization results the yield and yield components of maize were increasing with increasing $\mathrm{P}$ fertilizer application rates [13]. It is therefore expected that fertilizer placement and soil tilling affects $P$ distribution which in turn influences root distribution and is, consequently, related to $\mathrm{P}$ use efficiency by maize plants. $\mathrm{P}$ sufficiently for crop growth does not always exist in most soils because of loses due to erosion and high P fixation [14]. Low solubilities of soil $\mathrm{P}$ are the major problem in getting and keeping soil phosphate available to plants. Bedele district is which in Buno Bedele Zone of Oromia Region State and located at the southwestern parts of Ethiopia which of the maize was the leading cereal crop in area of cultivation and output or production. However, in study area the yield of maize obtained per hectare is still low due to low soil fertility and poor cultivation practices. As the population size increases the opportunity of expanding agricultural production in overall and corn production in particular through expansion in cultivated land would not been possible. Because of this, to increase yield per hectare use of high-quality seeds of desired and suitable crops with appropriate application type and rate of fertilizer were needed. The general objective of this study was to determine effects of $\mathrm{P}$ fertilizer rates and its placement methods on residual soil P, P uptake and yield of Maize. Therefore, this research work was proposed with the specific objectives of determine rates of $\mathrm{P}$ fertilizer on the residual soil $\mathrm{P}, \mathrm{P}$ uptake and yield of Maize and to determine the relative effectiveness of different methods of $\mathrm{P}$ fertilizer application on the residual soil P, P uptake and yield of Maize.

\section{Materials and Methods}

\subsection{Description of the Study Area and Area Coverage}

Bedele district, which in Buno Bedele zone of Oromia Regional National State, Southwestern Ethiopia. The district is located between $8^{\circ} 14^{\prime} 30^{\prime \prime} \mathrm{N}$ to $8^{\circ} 37^{\prime} 53^{\prime \prime} \mathrm{N}$ and $36^{\circ} 13^{\prime} 17^{\prime \prime} \mathrm{E}$ to $36^{\circ} 35^{\prime} 05^{\prime \prime} \mathrm{E}$ is about $483 \mathrm{~km}$ road distance south-west of Finfine. It is covers 74497.425 hectares of which 47,986 , 9477, and 10,120 hectares are cultivated, forest and grazing land, respectively [15]. The area is covered with variety of crops and species of natural vegetation. The dominant crops in the area are maize, tef, sorghum, finger millet and haricot bean. The major land use types are cultivated land/cropland, forestland and grazing land [15].

\subsection{Climate and Physical Features}

Bedele district is characterized by Desert and Woina dega traditional agro-climatic zone. The area has an altitude ranging from 1013 to 2390 meters above sea level with a humid agroecology. Fifteen-year (2006-2020) weather data ion collected at Bedele Meteorology Station show that Bedele has a uni-modal rainfall pattern and mean annual rainfall of $1942.1 \mathrm{~mm}$. The rainy season extends from April to October and the maximum rain is received in the months of May, June, July, August, September and October with the mean monthly rainfall exceeding $315 \mathrm{~mm}$. The annual average, mean minimum and mean maximum air temperatures are $19.5,13$ and $26^{\circ} \mathrm{C}$, respectively (Figure 2).

\subsection{Soil Type, Population Density, Vegetation and Farming System}

The soils of southwestern Ethiopia are in general classified as Nitosols according to FAO/UNESCO or Alfisols according to USDA soil classification systems [16].

Population density live in Bedele district about 61550 male and about 49023 female the total population live in Bedele district male and female are 110,573. The concentrated common vegetation in the district is: Bamboo, Gravilia robista, Cordia africana, acacia species, similarly cereals such as maize, sorghum, tef, and vegetables such as sweet potato, tomatoes, onion, chilies, also fruits such as avocado, mango, orange, banana, papaya, lemon. Farmers used traditional plough by oxen crop rotation practice to maintain soil fertility of the land and have been applying chemical fertilizers such as DAP and urea at the rates of $46 \mathrm{~kg} \mathrm{P}_{2} \mathrm{O}_{5} \mathrm{ha}^{-}$ ${ }^{1}$ and $46 \mathrm{~kg} \mathrm{~N}^{-1}$ for both maize and tef annually since 1995 when extension package program was launched around Bedele [15]. 


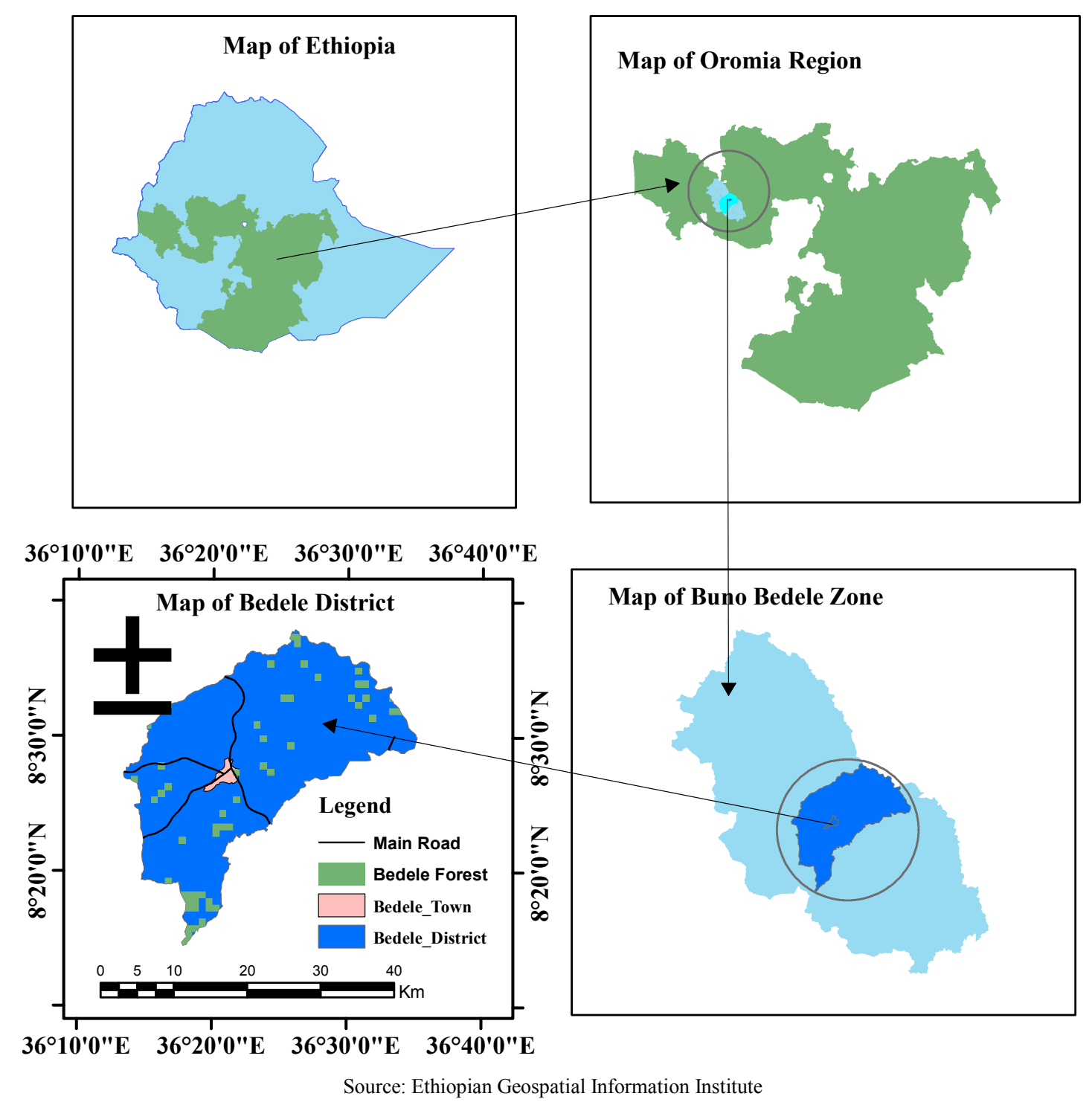

Figure 1. Location map of study area.

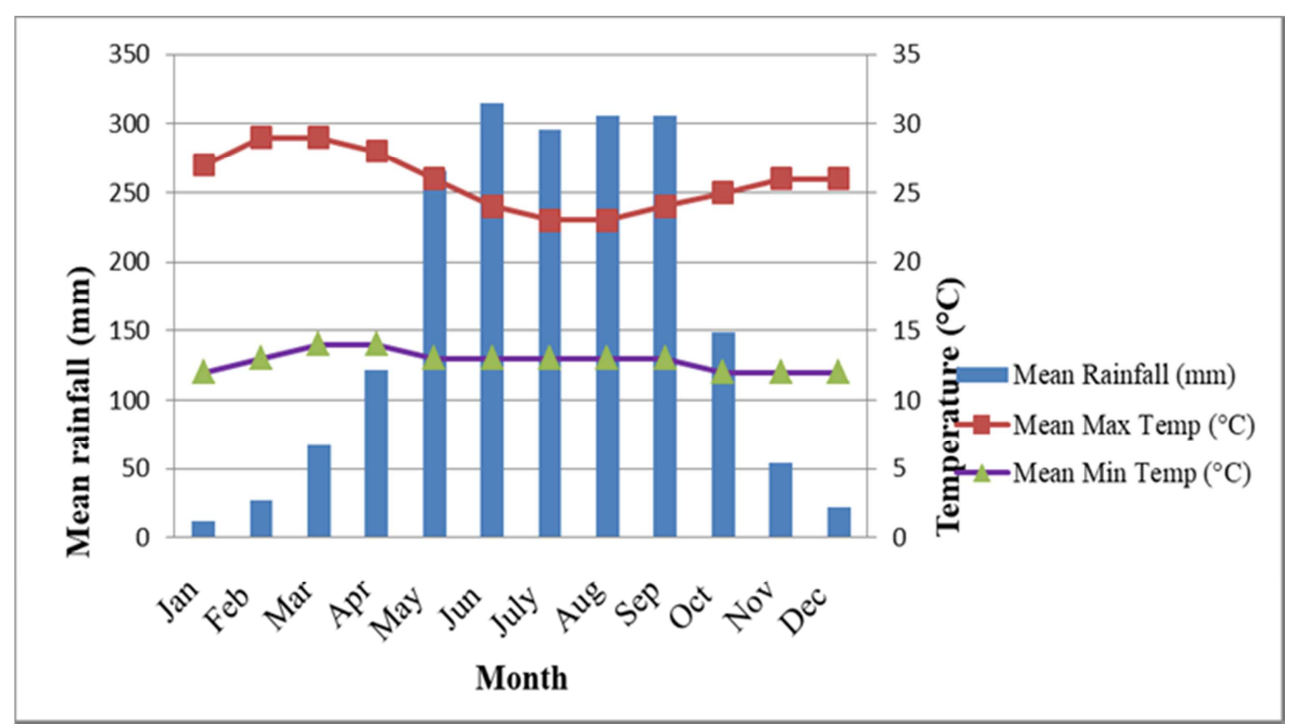

Source: Ethiopian Meteorological Agency, Bedele District Branch, 2020

Figure 2. Climatic data of monthly annual average mean rainfall, minimum and maximum temperature of the study area. 


\subsection{Treatment and Experimental Design}

The treatments used for this experiment were three methods of placement and four levels of $\mathrm{P}$ fertilizer. The factorial experiment was laid out in randomized complete block design with four levels of $\mathrm{P}$ fertilizers $\left(0,23,46\right.$, and $\left.69 \mathrm{P}_{2} \mathrm{O}_{5} \mathrm{~kg} \mathrm{ha}^{-1}\right)$ in a factorial combination with three placement methods of broadcasting of $\mathrm{P}_{2} \mathrm{O}_{5}$ fertilizer and seeds, surface banding $\mathrm{P}_{2} \mathrm{O}_{5}$ to the side of the seeds and Deep Banding $\mathrm{P}_{2} \mathrm{O}_{5}$ to below of the seeds up to $15 \mathrm{~cm}$. There were combined twelve treatments contained of four levels of $\mathrm{P}$ and three method of placement replicated three in a randomized complete block design. Half of recommended urea for Bedele district based on research finding of [17], $92 \mathrm{kgha}^{-1} \mathrm{~N}$ was supplied for each plot equal ratio at planting time and the remained dose was supplied after $30^{\text {th }}$ days of planting. The treatments were laid out in RCBD and replicated across treatment on $4 \mathrm{~m} * 3 \mathrm{~m}\left(12 \mathrm{~m}^{2}\right)$ for each plot and space between replication $1 \mathrm{~m}$, space between plot $0.50 \mathrm{~m}$ and space between plants $0.4 \mathrm{~m}$ and all area coverage $16 \mathrm{~m}^{*} 40.7 \mathrm{~m}\left(651.2 \mathrm{~m}^{2}\right)$. While conducting the experiment, other necessary agronomic management practices such as weeding, disease and insect pest control will be carried out uniformly for all treatments. The following treatment combinations were undertaken, $0 \mathrm{~kg} \mathrm{P}_{2} \mathrm{O}_{5}$ with broadcast, $0 \mathrm{~kg}$ $\mathrm{P}_{2} \mathrm{O}_{5}$ with surface banding, $0 \mathrm{~kg} \mathrm{P}_{2} \mathrm{O}_{5}$ with deep banding, 23 kg $\mathrm{P}_{2} \mathrm{O}_{5}$ with broadcast, $23 \mathrm{~kg} \mathrm{P}_{2} \mathrm{O}_{5}$ with surface banding, 23 $\mathrm{kg} \mathrm{P}_{2} \mathrm{O}_{5}$ with deep banding, $46 \mathrm{~kg} \mathrm{P}_{2} \mathrm{O}_{5}$ with broadcast, $46 \mathrm{~kg}$ $\mathrm{P}_{2} \mathrm{O}_{5}$ with surface banding, $46 \mathrm{~kg} \mathrm{P}_{2} \mathrm{O}_{5}$ with deep banding, 69 $\mathrm{kg} \mathrm{P}_{2} \mathrm{O}_{5}$ with broadcast, $69 \mathrm{~kg} \mathrm{P}_{2} \mathrm{O}_{5}$ with surface banding, and $69 \mathrm{~kg} \mathrm{P}_{2} \mathrm{O}_{5}$ with deep banding.

\subsection{Maize Variety and Fertilizer Materials}

Maize variety named BH661, was used which developed and released by DTMA (Drought Tolerant Maize for Africa) project in Ethiopia in 2011 at Bako Agricultural Research Center [18]. It is a drought resistant hybrid variety; performing well in agro-ecological range of 1600-2200 above sea level with rainfall range of 1000-1500 mm. It can give $95-120 \mathrm{q} \mathrm{ha}^{-1}$ and $65-85 \mathrm{q} \mathrm{ha}^{-1}$ grain yields under research station and farmers field, respectively at Bako agricultural research center. DAP is used as a source of both nitrogen and phosphorous, it contains $18 \% \mathrm{~N}$ and $46 \% \mathrm{P}_{2} \mathrm{O}_{5}$ and urea used as a source of nitrogen and it contains only $46 \%$ of $\mathrm{N}$.

\subsection{Agronomic Data}

From agronomic data, Phenology, growth, yield and major yield components were measured. These include plant height, days to tasseling was recorded based on number of days from planting up to when $50 \%$ of plants shed pollen and silking days require from planting to when $50 \%$ of the maize plant showed extrusion of silks in each plot, both days to $50 \%$ tasseling and silking were determined by similar way of visual observation, grain yield, dry ground biomass yield, 1000 grains weight and physiological maturity were recorded when $90 \%$ of the plants reached to their respective phonological stages. Plant height of six randomly taken maize plants marked within each plot. A carpenter's tape was used for measured the height from the ground level to the top-most leaf. Grain were determined by harvesting the entire net plot of $6 \mathrm{~m}^{2}$ and converted into kilogram per hectare. Dry Biomass Yield $\left(\mathrm{qt} \mathrm{ha}^{-1}\right)$ plants from the net plot area were harvested at physiological maturity and were weighed after sun dry. Harvest index: It was calculated from the ratio of the total grain yield threshed to the total biomass yield harvested from each plot. Stalk yield ( $\mathrm{qt}$ ha ${ }^{-1}$ ): Stalks yield was obtained from each unit plot including the straw of the sample plants of respective unit plot was dried in sun and weighed to record the final stalks yield plot $^{-1}$ and converted to $\mathrm{qt} \mathrm{ha}^{-1}$.

\subsection{Soil Sampling and Collection Techniques}

Soil samples were collected from the selected site at the depth of $0-20 \mathrm{~cm}$ of top soil used by auger from 15 to 20 spots before cultivation from each twelve treatments and then composite soil sample from each three blocks one soil sample and total the three soil sample were subjected to analyses of selected soil physic-chemical properties such as $\mathrm{pH}\left(\mathrm{H}_{2} \mathrm{O}\right)$, total nitrogen, organic carbon, available $\mathrm{P}$, exchangeable $\mathrm{K}$, exchangeable $\mathrm{Ca}$, exchangeable $\mathrm{Mg}$, and soil texture, bulk density, particle density, percent porosity and cation exchange capacity (CEC). In the same way, after harvested the yield soil samples were collected from three spots for each treatment in all plots thirty-six (36) soil samples were transferred to the laboratory for analysis. The collected samples were air-dried, ground, and passed through a $2 \mathrm{~mm}$ sieve to remove large particles, debris and stones and the physical and chemical properties were analyzed used standard procedures as described.

\subsection{Analysis of Selected Soil Physico-Chemical Properties}

Particle size distribution (soil texture) was analyzed by the modified Buoyoucos hydrometer method [19]. Soil bulk density was obtained from the undisturbed core sample using core method [20]. However, considering the average value of particle density of soil which is $2.65 \mathrm{gcm}^{-1}$. Then percent porosity of soil was computed from the values of bulk density and particle density as outlined by [21] as follows:

$$
\text { Percent porosity }(\% \mathrm{f})=1-\mathrm{Bd} / \mathrm{Pd} * 100
$$

The $\mathrm{pH}$ of the soil was determined potentiometerically using glass electrode $\mathrm{pH}$ meter in the supernatant suspension of 1:2.5, Soil to $\mathrm{H}_{2} \mathrm{O}$ [22]. Soil organic carbon was determined by the wet oxidation method as described by [23]. Determination of total $\mathrm{N}$ in soil of the samples was performed by the Kjeldahl method as described by [24]. And also, concentration of total $\mathrm{N}$ grain and stover was analyzed [25]. Exchangeable basic cations ( $\mathrm{Ca}, \mathrm{Mg}, \mathrm{K}$ and $\mathrm{Na}$ ) were extracted with $1 \mathrm{M}$ ammonium acetate at $\mathrm{pH}$ 7. Exchangeable $\mathrm{Ca}$ and $\mathrm{Mg}$ were determined from these extracted with atomic absorption spectroscopy (AAS) method. While exchangeable $\mathrm{K}$ and $\mathrm{Na}$ were determined from the same 
extracted with flame photometry [26]. Cation exchange capacity (CEC) of the soil was determined from ammonium acetate, saturated samples that was subsequently replaced by $\mathrm{Na}$ from a percolated Sodium chloride solution after removal of extra ammonium by repeated washed with alcohol. Exchangeable acidity was determined by saturated the soil samples with potassium chloride solution then filtered and titrated with sodium hydroxide as described by [22]. Available $\mathrm{P}$ in soil was determined by the Bray II [27] extraction method and Available $\mathrm{P}$ was determined from these extracted with Spectrophotometer method and total $\mathrm{P}$ analysis was done fusion with $\mathrm{Na}_{2} \mathrm{CO}_{3}[28,29]$. And the concentration $\mathrm{P}$ of the grain and stalks was analyzed by dryAshing (Calcination) method [30].

\subsection{Statistical Analysis}

Collected data were subjected to analysis of variance (ANOVA) by using Statistical Analysis System Software Version 9.3 [31] and significant treatment means was separated using Least Significance Difference (LSD) test and correlation coefficient within and between yield and agronomic parameters, and nutrient concentration in soil and plant and nutrient uptake was done.

\subsection{Partial Budget Analysis}

Economic analysis was made using the prevailing inputs at planting and for outputs at the time of the crop was harvested. Partial budget was estimated for average yield of the different treatment combinations. The prices of Maize, DAP and Urea were used for the analysis. The fertilizer cost was calculated for the cost of each fertilizers of DAP and Urea were collected at the time of planting. The average market prices of Maize grain at Bedele town were used. Fertilizer prices for DAP and Urea were 1997 and $1394 \mathrm{ETBqt}^{-1}$, respectively and the market price of maize grain was $6.5 \mathrm{ETBkg}^{-1}$ on the local market. Cost of land preparation, field management, harvest, transportation, protection, storage, post-harvest, and others would not include in the calculation. A treatment was considered worth to farmers when its minimum acceptable rate of return (MRR) is $100 \%$ [32], which is suggested to be realistic. This enables' to make farmer recommendations from marginal analysis. The economic analysis was based on the formula developed by [32].

\section{Results and Discussions}

A field experiment was carried out during 2020 cropping season to study effects of $\mathrm{P}$ fertilization rates and its placement methods on residual soil $\mathrm{P}$, yield, and $\mathrm{P}$ uptake of maize: the case of Bedele District. Record of the data collected from the field and laboratory analyses were subjected to statistical analysis and the results obtained are presented and discussed in the following sections.

\subsection{Soil Physical and Chemical Properties Before Planting}

The soil is clay in texture with clay content of $55.67 \%$ according, to [33] Soil with high clay content have sufficient particle to particle contact points to form strong bonds when the soil dries which can lead to the formation of strong crust. Similarly, frequent cultivation might have improved weathering of primary particles and contributed for the high clay fraction [34]. The $\mathrm{pH}$ of soils of study site value was 5.48 indicates strongly acidic according to [30] and [33] agreed on the result. The soil contained about $2.73 \%$ organic carbon which shows low according to [34]. Total N $0.16 \%$ also low as mentioned [33]. This indicated that organic and total $\mathrm{N}$ were highly affected due to poor agricultural practices. Soil $\mathrm{C}$ to $\mathrm{N}$ ratio might be an essential parameter in denoting soil decomposition processes and generally, soil organic matter with lower $\mathrm{C}$ to $\mathrm{N}$ ratio would be decomposed into more mobile materials or nutrients that were easy to be utilized [35]. $\mathrm{C}$ to $\mathrm{N}$ was $16.74: 1$ result showed that $\mathrm{C}$ to $\mathrm{N}$ ratio is an indicator of net $\mathrm{N}$ mineralization and accumulation in soils. Organic matter rich in carbon provides a large source of energy to soil microorganisms. And available P $1.51 \mathrm{ppm}$ is also low [36]. This may be because of high percent of clay content of the soil (Table 1). This result link with soils with higher clay content has high $\mathrm{P}$ retention capacity because clay particles have very large surface area per unit volume, which can adsorb P easily [37]. However, maize being a high $\mathrm{P}$-demanding crop, the level of available $\mathrm{P}$ values would not meet maize $P$ requirements, therefore additions of phosphate fertilizers is expected in order to achieve the optimum yield. Generally, the low available P of the soils could cause one of the major soils fertilities limiting factors in the study area. Besides, the cation exchange capacity (CEC) of the soil is $17.41 \mathrm{cmol}_{\mathrm{e}} / \mathrm{kg}$ which indicate medium $[38,33]$. The base cation indicates $\mathrm{Na}$ low, $\mathrm{K}$ very high, $\mathrm{Ca}$ very low and $\mathrm{Mg}$ medium according to $[30,33]$ and base saturation is medium (Table 1). [39] indicated, base saturation is positively related to soil $\mathrm{pH}$ because a high base saturation value would indicate that the exchange sites on a soil particle are dominated by non-acidic ions.

Table 1. Physical and chemical properties of experimental soils before planting.

\begin{tabular}{lllll}
\hline Soil properties & Sample $_{\mathbf{1}}$ & Sample $_{2}$ & Sample $_{\mathbf{3}}$ & Mean \\
\hline Particle size $(\%)$ & & & & 18 \\
Sand & 20 & 20 & 23 & 19.33 \\
Silt & 27 & 25 & 59 & 25.00 \\
Clay & 53 & 55 & Clay & 55.67 \\
Textural class & Clay & Clay & 2.65 & Clay \\
Average particle density $\left(\mathrm{g} / \mathrm{cm}^{3}\right)$ & 2.65 & 2.65 & 1.08 & 2.65 \\
Bulk density $\left(\mathrm{g} / \mathrm{cm}^{3}\right)$ & 1.16 & 1.14 & 59.29 & 1.13 \\
Percent porosity $(\%)$ & 56.11 & 56.97 & 0.16 & 57.46 \\
Total N $(\%)$ & 0.16 & 0.17 & 0.16 \\
\hline
\end{tabular}




\begin{tabular}{lllll}
\hline Soil properties & Sample $_{1}$ & Sample $_{2}$ & Sample $_{3}$ & Mean \\
\hline Av.P $(\mathrm{ppm})$ & 1.34 & 1.71 & 1.48 & 1.51 \\
Total P $(\mathrm{ppm})$ & 200.2 & 201.45 & 203.1 & 201.58 \\
$\mathrm{OC}(\%)$ & 2.85 & 2.78 & 2.57 & 2.73 \\
$\mathrm{C}: \mathrm{N}$ & $17.81: 1$ & $16.35: 1$ & $16.06: 1$ & $16.74: 1$ \\
$\mathrm{pH}\left(\mathrm{H}_{2} \mathrm{O}\right)$ & 5.43 & 5.39 & 5.62 & 5.48 \\
Exchangeable Acidity $\left(\mathrm{cmol}_{\mathrm{e}} / \mathrm{kg}\right)$ & 0.13 & 0.13 & 0.17 & 0.14 \\
$\mathrm{CEC}\left(\mathrm{cmol}_{\mathrm{e}} / \mathrm{kg}\right)$ & 19.03 & 16.03 & 17.17 & 17.41 \\
Exchangeable $\mathrm{Na}\left(\mathrm{cmol}_{\mathrm{e}} / \mathrm{kg}\right)$ & 0.21 & 0.23 & 0.18 & 0.209 \\
Exchangeable $\mathrm{K}\left(\mathrm{cmol}_{\mathrm{e}} \mathrm{kg}\right)$ & 2.37 & 2.84 & 2.30 & 2.50 \\
Exchangeable $\mathrm{Ca}\left(\mathrm{cmol}_{\mathrm{e}} / \mathrm{kg}\right)$ & 1.13 & 1.12 & 1.11 & 1.12 \\
Exchangeable $\mathrm{Mg}\left(\mathrm{cmol}_{\mathrm{e}} / \mathrm{kg}\right)$ & 1.84 & 1.84 & 1.81 & 1.83 \\
Base saturation $(\%)$ & 29.16 & 37.62 & 31.45 & 32.74 \\
\hline
\end{tabular}

\subsection{Maize Phenology, Growth, Agronomic Parameters and Yield}

The major agronomic parameters and yield components measured for this study include plant height, days 50\% to tasseling, days $50 \%$ to silking, grain yield, total above ground biomass yield, 1000 grains weight, Harvest index, Stalks yield and physiological maturity were recorded when $90 \%$ of the plants reached to their respective phonological stages.

\subsubsection{0\% Days to Tasseling and Silking}

Both main effect and interaction of $\mathrm{P}$ fertilizer rates and methods of fertilizer application were non-significant effect days to tasseling (Table 2). However, the longest days to reach $50 \%$ tasseling (84.3 days) was recorded from the control. Whereas, the shortest days to $50 \%$ tasseling $(81.8$ days) was recorded at the application of $\mathrm{P}$ fertilizer $69 \mathrm{~kg}$ $\mathrm{P}_{2} \mathrm{O}_{5} \mathrm{ha}^{-1}$. The higher fertilizer use of the crop leads the crop to forceful growth and ultimately the crop tassel early instead of lengthy vegetative growth. According, to [40] maize crop accumulates more heat units to tasseling with increasing the rate of $\mathrm{N}$ and vice versa. These results are agreement with those of $[41,42]$ who observed that a reduction in number of days to $50 \%$ tasseling in maize with increased rates of fertilizers. The result showed that both main effect and interaction of $\mathrm{P}$ fertilization and methods of fertilizer application were found to have non-significant effect on $50 \%$ days to siliking (Table 2). Though, the longest (91.3) days to reach $50 \%$ silking were recorded from the control. Whereas, the shortest ( 88.4 days) days to $50 \%$ silking was recorded at the application of $\mathrm{P}$ fertilizer $69 \mathrm{~kg} \mathrm{P}_{2} \mathrm{O}_{5} \mathrm{ha}^{-1}$. It is believed that silking is controlled less by environmental factor while more by genetic factor. Nevertheless, [5] application methods had no significant effect on tasseling and silking.

Table 2. Effects of $P$ fertilizer rate and its application on $50 \%$ days of tasseling and Silking.

\begin{tabular}{lll}
\hline $\mathbf{P}_{\mathbf{2}} \mathbf{O}_{\mathbf{5}}$ level $\left(\mathrm{Kg} \mathrm{ha}^{-\mathbf{1}}\right)$ & Days of tasseling & Days of silking \\
\hline 0 & 84.3 & 91.3 \\
23 & 83 & 89.9 \\
46 & 83.1 & 89.9 \\
69 & 81.8 & 88.4 \\
\hline
\end{tabular}

\subsubsection{Days to $90 \%$ of Maturity}

Days to physiological maturity were highly significantly $(\mathrm{P}<0.01)$ influenced by the main effect of $\mathrm{P}$ fertilizer rate.
But, main effects of application methods and the interaction of $\mathrm{P}$ fertilizer and placement methods had non-significantly ( $\mathrm{P}>0.05$ ) influenced $90 \%$ physiological maturity (Table 3 ). Accordingly, the longest (145) days to maturity was recorded by control or no application of $\mathrm{P}$ while the earliest (131.44) days to maturity were recorded in the application of $69 \mathrm{~kg}$ $\mathrm{P}_{2} \mathrm{O}_{5} \mathrm{ha}^{-1}$. At the optimum point of the $\mathrm{P}$ fertilization rate the maturity date was decrease. This finding was agreement with [43]. Who report that the two fertilizer types (blended fertilizer and recommended NP) had significantly reduced days to maturity when compared to the control.

Table 3. Effects of Phosphorus fertilizer rate and its methods of application on Maturity date.

\begin{tabular}{ll}
\hline $\mathbf{K g ~ P}_{\mathbf{2}} \mathbf{O}_{\mathbf{5}}$ level ha & Days to $\mathbf{9 0 \%}$ Maturity \\
\hline 0 & $145.00^{\mathrm{a}}$ \\
23 & $138.89^{\mathrm{b}}$ \\
46 & $138.11^{\mathrm{b}}$ \\
69 & $131.44^{\mathrm{c}}$ \\
LSD (5\%) & 5.41 \\
CV (\%) & 4.00 \\
Methods of application & \\
Broadcasting & 140.33 \\
Surface Banding & 136.58 \\
Deep banding & 138.00 \\
LSD (5\%) & $\mathrm{Ns}$ \\
\hline
\end{tabular}

Table 4. Effects of P fertilizer rate and its methods on Plant height.

\begin{tabular}{ll}
\hline $\mathbf{P}_{\mathbf{2}} \mathbf{O}_{\mathbf{5}}$ level $\left(\mathrm{kgha}^{-1}\right)$ & Plant height $(\mathbf{c m})$ \\
\hline 0 & $179.42^{\mathrm{c}}$ \\
23 & $188.02^{\mathrm{b}}$ \\
46 & $206.82^{\mathrm{a}}$ \\
69 & $199.98^{\mathrm{a}}$ \\
LSD (5\%) & 8.56 \\
Methods of application & \\
Broadcasting & $186.19^{\mathrm{b}}$ \\
Surface banding & $202.78^{\mathrm{a}}$ \\
Deep banding & $191.72^{\mathrm{b}}$ \\
LSD (5\%) & 7.42 \\
CV (\%) & 4.53 \\
\hline
\end{tabular}

\subsubsection{Plant Height (cm) and Thousand Grains Weight (gm)}

Plant height of maize was highly significantly $(\mathrm{P}<0.01)$ influenced by the main effect of both $\mathrm{P}$ fertilizer rates and its placement methods but, the interaction of $\mathrm{P}$ fertilizer and methods non-significantly $(\mathrm{P}>0.05)$ influenced (Table 4$)$ on maize growth. Accordingly, due to the methods of $\mathrm{P}$ placement the longest $(202.78 \mathrm{~cm})$ plant height was recorded with the application of $46 \mathrm{~kg} \mathrm{P}_{2} \mathrm{O}_{5} \mathrm{ha}^{-1} \mathrm{P}$ fertilizer rates on 
surface band application method and the shortest $(186.19 \mathrm{~cm})$ plant height were recorded by control or no application of $\mathrm{P}$ fertilizer rates. As fertilizer application rate increase the plant height also increase. The Increment of $P$ fertilizer rate had positive result on maize height. Similarly, [44] noted taller plants in the plots where $\mathrm{P}$ was applied at highest level as compared to plots where lower $\mathrm{P}$ fertilizer level is. The possible reason might be due to that soils low in $\mathrm{P}$ will adsorb huge amounts of $\mathrm{P}$ departure little for plants, when $\mathrm{P}$ was applied at the highest-level availability of $\mathrm{P}$ was increased that helped maize to achieve maximum height. Also, [45] described that plant height in maize increased with increase in $\mathrm{P}$ fertilizer level. Level beyond $46 \mathrm{~kg} \mathrm{P}_{2} \mathrm{O}_{5} \mathrm{ha}^{-1}$ was not effective indicating that plants have attained the potential height.

Thousand grain weight of maize was not significantly $(\mathrm{P}>0.05)$ influenced by the main effect of both $\mathrm{P}$ fertilizer rates and its placement methods and also their interaction. The thousand grain weight is an important yield component that helps a lot in the grain yield estimate. Maize produced the highest $(385.84 \mathrm{~g})$ thousand grain weight in the plots which received the highest $\mathrm{P}$ fertilizer $69 \mathrm{~kg} \mathrm{P}_{2} \mathrm{O}_{5} \mathrm{ha}^{-1}$ while, the lowest (353.51g) thousand grain weight without application $\mathrm{P}$ fertilizer (control). This result agreement with [46] who reported that $P$ fertilizer level has no significant effect on thousand grain yield weight. Likewise, [47, 48] observed an increase in thousand grain weight with increase in NP application level. P being responsible for good root growth directly influenced the thousand grain weight because $\mathrm{P}$ fertilizer at the rate of $0 \mathrm{~kg} \mathrm{ha}^{-1}$ (control plots) resulted in the least thousand grain weight [48]. Similarly, [49] specified that $\mathrm{P}$ fertilizer rate did not show a significant effect on thousand grain weight.

\subsubsection{Dry Biomass Yield (qt hat ${ }^{-1}$ ) and Grain Yield (qt hat ${ }^{-1}$ )}

Dry biomass yield were highly significantly $(\mathrm{P}<0.01)$ influenced by the main effect of both $\mathrm{P}$ fertilizer rates and its placement methods, and also the interaction between main effect of both $\mathrm{P}$ fertilizer rates and its placement methods (Table 5). Generally, the occurrence of interaction effect between the factors on the measured variables showed that the main effects of $\mathrm{P}$ fertilizer rates and its placement methods factors influence each other in affecting the aspect. Maize produced the highest (142.11 qt ha $\left.{ }^{-1}\right)$ dry biomass yield of maize with application of the highest $\mathrm{P}$ fertilizer 69 $\mathrm{kg} \mathrm{P}_{2} \mathrm{O}_{5} \mathrm{ha}^{-1}$ on the surface band placement method and the lowest $\left(23.4 \mathrm{qt} \mathrm{ha}^{-1}\right)$ dry biomass yield of maize without application P fertilizer (control) on broadcasting application method. This finding is in agreement with [50] who reported that increased $\mathrm{P}$ level increases dry biomass yield. Dry biomass yields were more significantly affected by $\mathrm{P}$ fertilizer rates than grain yield [49].

Table 5. Effects of P fertilizer rate and its methods on Biomass yield weight $\left(q t\right.$ ha $\left.{ }^{-1}\right)$.

\begin{tabular}{llll}
\hline \multirow{2}{*}{$\mathbf{P}_{2} \mathbf{O}_{\mathbf{5}}$ level $\left(\mathrm{kgha}^{-\mathbf{1}}\right)$} & \multicolumn{3}{l}{ Placement methods of phosphorus fertilizer } \\
\cline { 2 - 4 } & Broadcasting & Surface banding & Deep banding \\
\hline 0 & $23.4^{\mathrm{k}}$ & $63.89^{\mathrm{h}}$ & $48.29^{\mathrm{i}}$ \\
23 & $43.65^{\mathrm{j}}$ & $113.84^{\mathrm{b}}$ & $82.12^{\mathrm{f}}$ \\
46 & $65.24^{\mathrm{h}}$ & $103.19^{\mathrm{d}}$ & $86.84^{\mathrm{e}}$ \\
69 & $68.84^{\mathrm{g}}$ & $142.11^{\mathrm{a}}$ & $105.93^{\mathrm{c}}$ \\
LSD (5\%) & 2.10 & & \\
CV $(\%)$ & 1.57 & & \\
\hline
\end{tabular}

The mean grain yield of maize was highly significantly $(\mathrm{P}<0.01)$ influenced by both main effect of $\mathrm{P}$ fertilizer rates and its placement methods, and also by their interaction (Table 6). Normally, the existence of interaction effect between the factors on the measured variables showed that the main effects of $\mathrm{P}$ fertilizer rates and its placement methods factors influence each other on grain yield of maize. The maximum 78.40qt ha ${ }^{-1}$ grain yield of maize was recorded with application of $69 \mathrm{~kg}$ $\mathrm{P}_{2} \mathrm{O}_{5} \mathrm{ha}^{-1}$ was applied at surface banding to the side of the seeds this maximum grain yield of maize shows between the potential production BH661 of maize variety which $65-85 \mathrm{qt}$ $\mathrm{ha}^{-1}$ grain yields under farmers field [18]. The minimum grain yield $10.97 \mathrm{qt} \mathrm{ha}^{-1}$ of maize was recorded at control plot on broadcasting placement method. These results showed increase over control was about $67.43 \mathrm{qt} \mathrm{ha}^{-1}$. As $\mathrm{P}$ fertilization rate increase the grain yield of maize also increase. This finding was agreement with [51] who reported that, the surface band placement method gave higher yield of maize thatother placement methods. Grain yield of maize responded positively and significantly to $\mathrm{P}$ fertilizer application rates [52]. Likewise, [53] stated that the grain yield showed significant increasing trend with the increase in P fertilizer rate. Moreover, [49] also reported significant maize yield increase due to $\mathrm{P}$ application.

Table 6. Effects of Phosphorus fertilizer rate and its methods on Grain yield weight $\left(q t h a^{-1}\right)$.

\begin{tabular}{llll}
\hline \multirow{2}{*}{$\mathbf{P}_{2} \mathbf{O}_{5}$ level $\left(\mathbf{k g h a}^{-1}\right)$} & \multicolumn{2}{l}{ Placement methods of phosphorus fertilizer } & Deep banding \\
\cline { 2 - 4 } & Broadcasting & Surface banding & $17.63^{\mathrm{f}}$ \\
\hline 0 & $10.97^{\mathrm{g}}$ & $26.00^{\mathrm{e}}$ & $38.07^{\mathrm{d}}$ \\
23 & $16.9^{\mathrm{f}}$ & $56.77^{\mathrm{b}}$ & $42.87^{\mathrm{c}}$ \\
46 & $25.8^{\mathrm{e}}$ & $58.03^{\mathrm{b}}$ & $55.23^{\mathrm{b}}$ \\
69 & $34.37^{\mathrm{d}}$ & $78.40^{\mathrm{a}}$ & \\
LSD (5\%) & 3.96 & & \\
CV (\%) & 6.08 & & \\
\hline
\end{tabular}




\subsubsection{Stalk Yield (qt ha ${ }^{-1}$ ) and Harvest Index}

The mean stalk yield of maize was highly significantly $(\mathrm{P}<0.01)$ influenced by both main effect of $\mathrm{P}$ fertilization rates and its placement methods, and also, highly significantly influenced by placement methods of $\mathrm{P}$ fertilizer and the interaction of $\mathrm{P}$ fertilization rates (Table 7). The maximum 63.70qt $\mathrm{ha}^{-1}$ stalk yield of maize was recorded with application of $69 \mathrm{~kg} \mathrm{P}_{2} \mathrm{O}_{5} \mathrm{ha}^{-1}$ was applied at surface banding to the side of the seeds and minimum $12.40 \mathrm{qt} \mathrm{ha}^{-1}$ stalk yield of was recorded at control plot on broadcasting placement method. This might be due to the fact that crops supplied with adequate nutrients have more vegetative growth, longer linear growth rate and more dry matter accumulation which directly related to an increment in straw yield [54].

Table 7. Effects of P fertilizer rate and its methods on Stalk yield ( $q$ t ha $\left.{ }^{-1}\right)$.

\begin{tabular}{llll}
\hline \multirow{2}{*}{$\mathbf{P}_{2} \mathbf{O}_{\mathbf{5}}$ level $\left(\mathbf{k g h a}^{-1}\right)$} & \multicolumn{2}{l}{ Placement methods of phosphorus fertilizer } \\
\cline { 2 - 4 } & Broadcasting & Surface banding & Deep banding \\
\hline 0 & $12.40^{\mathrm{g}}$ & $37.87^{\mathrm{e}}$ & $30.67^{\mathrm{ef}}$ \\
23 & $26.73^{\mathrm{gf}}$ & $57.10^{\mathrm{b}}$ & $44.06^{\mathrm{d}}$ \\
46 & $39.43^{\mathrm{e}}$ & $45.17^{\mathrm{d}}$ & $43.97^{\mathrm{d}}$ \\
69 & $34.43^{\mathrm{ef}}$ & $63.70^{\mathrm{a}}$ & $50.70^{\mathrm{c}}$ \\
LSD $(5 \%)$ & 4.92 & & \\
CV $(\%)$ & 7.17 & & \\
\hline
\end{tabular}

The mean harvest index of maize was highly significantly $(\mathrm{P}<0.01)$ influenced by both main effect of $\mathrm{P}$ fertilization rates and its placement methods, and also, highly significantly influenced by placement methods of $\mathrm{P}$ fertilizer and the interaction of $\mathrm{P}$ fertilization rates. (Table 8). Depending mean of $\mathrm{P}$ rate the harvest index in maize increased with increase in $\mathrm{P}$ fertilizer levels. However, the highest harvest index was recorded with application of $69 \mathrm{~kg}$ $\mathrm{P}_{2} \mathrm{O}_{5} \mathrm{ha}^{-1}$ and the minimum harvest index was determined on control (no application of fertilizer). The increase in harvest index with higher $\mathrm{P}$ levels might be due to the increase in yield and yield components of maize with higher P rates [44]. This low harvest index might be associated with lack of nutrients and not easily available form for the crop to use. This result in agreement with $[55,56]$ who reported that application of B, Zn with NPK increase on yield components of wheat especially on harvest index and grain yield.

Table 8. Effects of $P$ fertilizer rate and its methods on Harvest index.

\begin{tabular}{|c|c|c|c|c|}
\hline \multirow{2}{*}{$\mathrm{P}_{2} \mathrm{O}_{5}$ level $\left(\mathrm{kgha}^{-1}\right)$} & \multicolumn{4}{|c|}{ Placement methods of phosphorus fertilizer } \\
\hline & Broadcasting & Surface banding & Deep banding & Mean \\
\hline 0 & $46.97^{\mathrm{dc}}$ & $40.66^{\mathrm{e}}$ & $36.52^{\mathrm{e}}$ & $41.38^{\mathrm{b}}$ \\
\hline 23 & $38.81^{\mathrm{e}}$ & $49.89^{\text {bdc }}$ & $46.37^{\mathrm{d}}$ & $45.02^{\mathrm{b}}$ \\
\hline 46 & $39.55^{\mathrm{e}}$ & $56.22^{\mathrm{a}}$ & $49.37^{\text {bac }}$ & $48.38^{\mathrm{a}}$ \\
\hline 69 & $49.98^{\text {bdc }}$ & $55.17^{\mathrm{ba}}$ & $52.15^{\text {bac }}$ & $52.43^{\mathrm{a}}$ \\
\hline $\operatorname{LSD}(0.05)$ & 5.42 & & & \\
\hline CV $(\%)$ & 6.84 & & & \\
\hline
\end{tabular}

\subsection{Phosphorous and Nitrogen Concentrations in the Soil Residual Soil P}

Table 9. Effects of $P$ fertilizer rate and its methods on residual phosphorus in soil.

\begin{tabular}{ll}
\hline $\mathbf{P}_{2} \mathbf{O}_{\mathbf{5}}$ level $\left(\mathrm{kgha}^{-\mathbf{1}}\right)$ & Residual phosphorus in the soil (ppm) \\
\hline 0 & $1.312^{\mathrm{c}}$ \\
23 & $7.600^{\mathrm{b}}$ \\
46 & $9.290^{\mathrm{b}}$ \\
69 & $11.790^{\mathrm{a}}$ \\
LSD (5\%) & 2.40 \\
Methods of application & \\
Broadcasting & $5.548^{\mathrm{b}}$ \\
Surface banding & $10.067^{\mathrm{a}}$ \\
Deep banding & $6.88^{\mathrm{b}}$ \\
LSD (5\%) & 2.08 \\
CV (\%) & 32.75 \\
\hline
\end{tabular}

The residual soil $\mathrm{P}$ after harvest against treatments is indicated in (Table 9). Residual soil P extracted with Bray II is highly significantly $(\mathrm{P}<0.01)$ influenced by $\mathrm{P}$ fertilizer rates and its placement methods. However, the interaction between $\mathrm{P}$ fertilization rates and its placement methods, non-significant. Surface banding $P$ fertilizer to the sides of the seeds highly significantly $(p<0.01)$ increase residual $P$ over deep banding $\mathrm{P}$ fertilizer below the seeds and broadcasting $\mathrm{P}$ fertilizer and seeds (Table 9). However, there was non-significant difference among broadcasting $\mathrm{P}$ and seeds, deep banding below the seeds on residual $P$.

An average of overall $P$ fertilizer rates, the initial level of available soil $\mathrm{P}$ which was $1.51 \mathrm{ppm}$ before planting (Table 1) the residual soil $P$ increased to $10.067,6.88$ and 5.548 ppm when surface banding $\mathrm{P}$ fertilizer to the side of the seeds, deep banding $\mathrm{P}$ fertilizer below the seeds and broadcasting $\mathrm{P}$ fertilizer with seeds, where obtained, respectively (Table 9). This highest level of Bray II residual soil $\mathrm{P}$ result showed due to surface banding $\mathrm{P}$ to the side of the seeds agreed with the highest grain yield and grain $\mathrm{P}$ uptake (Table $6 ; 13$ ). Contrast of total $\mathrm{P}$ in the soil and residual soil $\mathrm{P}$, grain and Stover up take of $\mathrm{P}$ by maize plant less than the total $\mathrm{P}$ in the soil. This result was showed due to 
high fixation P by aluminum or iron in acidic soil of the study area (Table 10).

Table 10. Total $P$ in the soil, Residual soil $P$, grain and Stover up take by plant.

\begin{tabular}{llllll}
\hline $\mathbf{P}_{\mathbf{2}} \mathbf{O}_{\mathbf{5}}$ level $\left(\mathbf{k g h a}^{\mathbf{- 1}}\right)$ & Total $\mathbf{P}(\mathbf{p p m})$ & Residual $\mathbf{P}(\mathbf{p p m})$ & Total P in Grain $(\mathbf{p p m})$ & Total $\mathbf{P}$ in Stover $(\mathbf{p p m})$ & $\mathbf{U n a v a i l a b l e ~} \mathbf{P}(\mathbf{p p m})$ \\
\hline 0 & 213.48 & 1.31 & 0.35 & 1.35 & 210.47 \\
23 & 222.26 & 7.6 & 0.55 & 1.38 & 212.73 \\
46 & 238.13 & 9.29 & 0.98 & 1.45 & 226.41 \\
69 & 250.46 & 11.79 & 1.15 & 1.48 & 236.04 \\
\hline
\end{tabular}

More than $90 \%$ of total $\mathrm{P}$ is present as insoluble and fixed forms including primary phosphate minerals, humus $\mathrm{P}$, insoluble phosphate of calcium, iron and aluminum and $\mathrm{P}$ fixed by hydrous oxides and silicate minerals. This fraction can be described as nonlabile. Although, $\mathrm{P}$ can become unavailable through precipitation, which happens if plant available inorganic $\mathrm{P}$ reacts with dissolved iron, aluminum, manganese in acid soils, or calcium in alkaline soils to form phosphate minerals [57]. These results is in agreement with [14] specified that at $\mathrm{pH}$ lower than 5.5, the retention results mostly from the reactions with Iron, Aluminum and their hydrous oxides resulting into low forms of available P. Therefore, it is essential to maintain the reaction of the soil around $\mathrm{pH} 7$ so that the chemical and biological conditions become optimum for plant growth and development. Based on the $\mathrm{P}$ fertilizer application levels, the residual soil $\mathrm{P}$ was recorded at $69 \mathrm{~kg} \quad \mathrm{P}_{2} \mathrm{O}_{5} \mathrm{ha}^{-1}$ was significantly $(\mathrm{p}<0.01)$ influenced and higher than all $\mathrm{P}$ fertilizer application rates. While, residual soil $\mathrm{P}$ obtained at control was significantly $(\mathrm{P}<0.01)$ lower than all $\mathrm{P}$ fertilizer application rates (Table 9). Also, application of $69 \mathrm{~kg} \mathrm{P}_{2} \mathrm{O}_{5} \mathrm{ha}^{-1}$ of applied $\mathrm{P}$ fertilizer, the residual soil $\mathrm{P}$ was (11.79 ppm) improved by $10.28 \mathrm{ppm}$ above the initial soil $\mathrm{P}$ (1.51 ppm) after harvest. However, the residual soil $\mathrm{P}$ at control was decreased by $0.198 \mathrm{ppm}$ under soil $\mathrm{P}$ before harvest which might be due to $\mathrm{P}$ uptake of plant or fixation or both. Between the above three P placements methods, the highest $(10.067 \mathrm{ppm})$ residual soil $\mathrm{P}$ level of increment was gained by the use of surface banding and the lowest $(5.548 \mathrm{ppm})$ by using broadcasting methods of $\mathrm{P}$ application. The residual soil $\mathrm{P}$ showed an increase with the application of $\mathrm{P}$ fertilizer in the form of di-ammonium phosphate with considerable differences across placement methods [58]. Therefore, it can be educated that the variation of $\mathrm{P}$ as affected by $\mathrm{P}$ placement methods has less to do with the subsequent $\mathrm{P}$ uptake pattern of the maize plant [58]. Likewise, [53] reported that residual $\mathrm{P}$ results in a slightly increasing trend with the addition of $\mathrm{P}$ fertilizer rate, which increased compared with the no $\mathrm{P}$ fertilizer treatment.

\subsection{Total Soil P (ppm) and Total Soil N (\%) After Harvest}

The concentration of total $\mathrm{P}$ in the soil after harvest was highly significantly $(\mathrm{P}<0.01)$ affected due to $\mathrm{P}$ fertilization application rate and significantly $(\mathrm{P}<0.05)$ due to $\mathrm{P}$ placement methods. Whereas, their combined effects of methods of $\mathrm{P}$ placement and $\mathrm{P}$ application rates did not significant affected interaction between them (Table 11). Due to $\mathrm{P}$ fertilization rate the maximum total $\mathrm{P}(250.46 \mathrm{ppm})$ obtained at $69 \mathrm{kgP}_{2} \mathrm{O}_{5}$ ha $^{-1}$ was significantly $(\mathrm{p}<0.01)$ higher than that at $23 \mathrm{~kg} \mathrm{P}_{2} \mathrm{O}_{5} \mathrm{ha}^{-1}$ and without $\mathrm{P}$ application. Also, total $\mathrm{P}$ recorded at $46 \mathrm{kgP}_{2} \mathrm{O}_{5} \mathrm{ha}^{-1}$ was statistically significantly $(\mathrm{p}<0.05)$ higher than total $\mathrm{P}$ obtained from at $23 \mathrm{P}_{2} \mathrm{O}_{5} \mathrm{~kg} \mathrm{P}_{2} \mathrm{O}_{5} \mathrm{ha}^{-1}$ and no $\mathrm{P}$ application (Table 11). However, due to $\mathrm{P}$ placement the maximum total $\mathrm{P}$ (236.41 ppm) obtained at surface banding placement method was significant $(\mathrm{P}<0.05)$ higher than at broadcast placement but, deep band placement was showed non-significant difference within surface band placement.

Table 11. Main effects of $P$ fertilizer rate and its methods on Total $P$ in soil after harvest.

\begin{tabular}{ll}
\hline $\mathbf{P}_{\mathbf{2}} \mathbf{O}_{\mathbf{5}}$ level $\left(\mathrm{kgha}^{-\mathbf{1}}\right)$ & Total phosphorus (ppm) \\
\hline 0 & $213.48^{\mathrm{c}}$ \\
23 & $222.26^{\mathrm{c}}$ \\
46 & $238.13^{\mathrm{b}}$ \\
69 & $250.46^{\mathrm{a}}$ \\
LSD (5\%) & 9.57 \\
Method of application & \\
Broadcasting & $225.60^{\mathrm{b}}$ \\
Surface banding & $236.41^{\mathrm{a}}$ \\
Deep banding & $231.24^{\mathrm{a}}$ \\
LSD $(5 \%)$ & 8.28 \\
CV (\%) & 4.23 \\
\hline
\end{tabular}

The average across all plot treatments, as $\mathrm{P}$ fertilization rate increase the total $\mathrm{P}$ in the soil also increase. All $\mathrm{P}$ placement methods increased the initial level of total soil $\mathrm{P}$ (201.58 ppm) (Table 1). In the same way, [59, 60] reported that different methods of $\mathrm{P}$ application increased the initial total soil phosphorus. The highest (236.41 ppm) mean of total soil $\mathrm{P}$ was obtained from the plots where $\mathrm{P}$ fertilizer was surface banded at the sides of the seeds. Whereas the least $(225.60 \mathrm{ppm})$ total soil $\mathrm{P}$ value was recorded from broadcasting phosphorus fertilizer (Table 11). This result agreement in mark with [61], the total $\mathrm{P}$ contents of Ethiopian soils have ranged from 200 to $800 \mathrm{mg} \mathrm{kg}$. Appropriate land management of the experimental field combined with a lengthy period of time of application of inorganic phosphate fertilizer from year to year might donate to generally high level of total soil P. Although, the effects of $\mathrm{P}$ fertilizer application rates, its different methods of $\mathrm{P}$ fertilizer placement, and their interaction on total $\mathrm{N}$ in the soil were highly significantly different. Though, the generally effect of surface banding $\mathrm{P}$ resulted in more soil $\mathrm{N}$ than both the outstanding methods of $\mathrm{P}$ placement. This indicated that surface banding $\mathrm{P}$ to the side of the seeds had mostly apparent benefit on total $\mathrm{N}$ in the soil (Table 12). There was also an affinity of increasing total $\mathrm{N}$ in the soil with increasing $\mathrm{P}$ rates on the surface banding placement method than other placement methods. This strength is due to the 
application of enough amount of $\mathrm{N}\left(92 \mathrm{~kg} \mathrm{Nha}{ }^{-1}\right)$ to the experimental field in the form of DAP and urea. According, to [60] research done at several locations in Ethiopia showed that after harvest soil $\mathrm{N}$ was increased by the application of $\mathrm{N}$ fertilizer. The higher concentrations of available nitrogen in soils after $\mathrm{N}$ dose has been underlined by [62] who testified that continuous use of nitrogenous fertilizers increased the available $\mathrm{N}$ status of the soil.

Table 12. Effects of $P$ fertilizer rate and its methods on total $N$ in the soil after harvest.

\begin{tabular}{llll}
\hline \multirow{2}{*}{$\mathbf{P}_{2} \mathbf{O}_{5}$ level $\left(\mathbf{k g} / \mathbf{h a}^{-1}\right)$} & \multicolumn{2}{l}{ Placement method of phosphorus fertilizer } & Deep banding \\
\cline { 2 - 4 } & Broadcasting & Surface banding & $0.38000^{\mathrm{d}}$ \\
\hline 0 & $0.37333^{\mathrm{d}}$ & $0.38667^{\mathrm{cd}}$ & $0.39333^{\text {cd }}$ \\
46 & $0.36667^{\mathrm{e}}$ & $0.4100^{\mathrm{b}}$ & $0.4200^{\mathrm{b}}$ \\
69 & $0.4000 \mathrm{c}$ & $0.4200^{\mathrm{b}}$ & $0.400^{\mathrm{c}}$ \\
LSD (5\%) & $0.3900^{\text {cd }}$ & $0.4333^{\mathrm{a}}$ & \\
CV $(\%)$ & 0.0131 & & \\
\hline
\end{tabular}

\subsection{Total P and Total N Uptake by Maize Grain and Stover}

\subsubsection{Concentration of Total P in Maize Grain and Stover (\%)}

Total $\mathrm{P}$ concentration in grain were highly significantly $(\mathrm{P}<0.01)$ influenced by the main effect of both $\mathrm{P}$ fertilizer rates and its placement methods (Table 13). The result shows that surface banded placement $\mathrm{P}$ fertilizer increased $\mathrm{P}$ uptake more than the other placements such as deep band and broadcast. The next to surface band placement the result shows deep band placement increased $\mathrm{P}$ uptake more than the broadcast placement. These finding also agreement with [63] who reported that the planter banded $\mathrm{P}$ increase $\mathrm{P}$ uptake more than the other placement at most sites' placement was significant on maize grain. However, the main effect of $\mathrm{P}$ fertilization rates and placement methods do not have significant $(\mathrm{P}>0.05)$ effect on maize stalks. There were highly difference among treatments and the highest (1.47\%) $\mathrm{P}$ uptake by grain was recorded in treatment treated by $69 \mathrm{~kg}$ $\mathrm{P}_{2} \mathrm{O}_{5} \mathrm{ha}^{-1}$ at surface banding $\mathrm{P}$ fertilizer to side of the seeds and Stalks $(1.57 \%)$ was received in treatment treated also by $69 \mathrm{~kg} \mathrm{P}_{2} \mathrm{O}_{5} \mathrm{ha}^{-1}$ at deep banding below the seeds and the lowest $(0.13 \%$ and $1.31 \%)$ respectively recorded in control.

Table 13. Effects of $P$ fertilizer rate and its methods on total $P$ in grain and Stalks.

\begin{tabular}{|c|c|c|c|c|c|c|}
\hline \multirow{3}{*}{$\mathrm{P}_{2} \mathrm{O}_{5}$ level $\left(\mathrm{kg} / \mathrm{ha}^{-1}\right)$} & \multicolumn{6}{|c|}{ Placement method of phosphorus fertilizer } \\
\hline & \multicolumn{3}{|c|}{ Total phosphorus in grain $(\%)$} & \multicolumn{3}{|c|}{ Total phosphorus in stalks (\%) } \\
\hline & Broadcasting & Surface banding & Deep banding & Broadcasting & Surface banding & Deep banding \\
\hline 0 & $0.1300^{\mathrm{h}}$ & $0.49333^{\mathrm{f}}$ & $0.3333^{\mathrm{g}}$ & 1.31 & 1.41 & 1.34 \\
\hline 23 & $0.60333^{\mathrm{e}}$ & $0.72667^{\mathrm{d}}$ & $0.3233^{\mathrm{g}}$ & 1.36 & 1.40 & 1.36 \\
\hline 46 & $1.08667^{\mathrm{c}}$ & $0.49333^{\mathrm{f}}$ & $1.34667^{\mathrm{b}}$ & 1.36 & 1.50 & 1.50 \\
\hline 69 & $0.81667^{\mathrm{d}}$ & $1.4700 \mathrm{a}$ & $1.16667^{\mathrm{c}}$ & 1.43 & 1.44 & 1.57 \\
\hline $\operatorname{LSD}(5 \%)$ & 0.0932 & & & ns & & \\
\hline
\end{tabular}

Increase stalks at higher $\mathrm{P}$ level than lower $\mathrm{P}$ level indicate more $\mathrm{P}$ availability at higher $\mathrm{P}$ rates [44]. According, to [64] who reported that application of different blended fertilizer rates on $\mathrm{P}$ uptake in grain and stalks showed high difference and increasing trends. Due to the blended fertilizer treatment, there were highly difference among treatments and the highest $\mathrm{P}$ uptake by grain was obtained lowest result was recorded in treatment treated by N, P, S, Zn, B and obtain the heights value from Stalks was received in treatment treated by DAP. Similarly, [65] reported that the interaction of $P$ levels with methods of $\mathrm{P}$ application was significant for total $\mathrm{P}$ uptake grain and stalk $\mathrm{P}$ contents and results showed the $\mathrm{P}$ concentration in the straw greater than the concentration of $\mathrm{P}$ in the grain. The response to increased application of $\mathrm{P}$ fertilizer rate was associated with an improvement in the concentrations and uptakes of $\mathrm{P}$ and $\mathrm{N}$ by maize plant that could explanation for the increase in yield.

\subsubsection{Concentration of Total $N$ in Maize Grain and Stalks (\%)}

Total $\mathrm{N}$ concentration in grain and stalks were highly significantly $(\mathrm{P}<0.01)$ influenced by the main effect of both $\mathrm{P}$ fertilizer rates and its placement methods. However, the interaction between main effect of both $\mathrm{P}$ fertilizer rate and its placement methods was no significant $(\mathrm{P}>0.05)$ difference. Among the methods of $\mathrm{P}$ placement, the highest concentration of $\mathrm{N}(0.178 \%)$ in grain was obtained by deep banding $\mathrm{P}$ below the seeds while the least grain nitrogen concentration $(0.158 \%)$ recorded from broadcasting phosphorus and seeds (Table 14).

Among the methods of $\mathrm{P}$ placement, the highest concentration of nitrogen (1.6275\%) in Stalks was obtained by deep banding $\mathrm{P}$ below the seeds while the least stalks $\mathrm{N}$ concentration $(1.4115 \%)$ recorded from broadcasting $\mathrm{P}$ and seeds (Table 14). Usually, the amount of interaction effect between the factors on the measured variables showed that the main effects of $\mathrm{P}$ fertilizer rates and its placement methods factors influence each other in affecting the aspect. Similarly, [65] reported that the interaction of $\mathrm{P}$ levels with methods of $\mathrm{P}$ application was significant for total $\mathrm{P}$ uptake grain and straw $\mathrm{P}$ contents and results showed the $\mathrm{P}$ concentration in the straw greater than the concentration of $\mathrm{P}$ 
in the grain. Also, [64] reported that application of different blended fertilizer rates on $\mathrm{P}$ uptake in grain and stalks showed high difference and increasing trends. Due to the blended fertilizer treatment, there were highly difference among treatments and the highest $\mathrm{P}$ uptake by grain was obtained lowest result was recorded in treatment treated by NPSZnB and obtain the heights value from Stalks was received in treatment treated by DAP.

Table 14. Effects of P fertilizer rate and its methods on total $N$ in Grain and Stalks.

\begin{tabular}{lll}
\hline Treatment $\mathbf{P}_{\mathbf{2}} \mathbf{O}_{\mathbf{5}}$ level $\mathbf{~ k g / h a}$ & Total Nitrogen in grain (\%) & Total Nitrogen in Stalks (\%) \\
\hline 0 & $0.156^{\mathrm{b}}$ & $1.156^{\mathrm{d}}$ \\
23 & $0.169^{\mathrm{a}}$ & $1.399^{\mathrm{c}}$ \\
46 & $0.176^{\mathrm{a}}$ & $1.622^{\mathrm{b}}$ \\
69 & $0.177^{\mathrm{a}}$ & $1.906^{\mathrm{a}}$ \\
LSD (5\%) & 0.0118 & 0.0828 \\
Method of application & & $1.4115^{\mathrm{c}}$ \\
Broadcasting & $0.158^{\mathrm{b}}$ & $1.52408^{\mathrm{b}}$ \\
Surface banding & $0.172^{\mathrm{a}}$ & $1.62750^{\mathrm{a}}$ \\
Deep banding & $0.178^{\mathrm{a}}$ & 0.0717 \\
LSD (5\%) & 0.0102 & 5.57 \\
CV (\%) & 7.15 & \\
\hline
\end{tabular}

Table 15. Some Soil chemical properties after harvest.

\begin{tabular}{|c|c|c|c|c|c|c|c|}
\hline $\begin{array}{l}\text { Treatment } \mathrm{P}_{2} \mathrm{O}_{5} \\
\text { level kg/ha }\end{array}$ & $\mathrm{pH}\left(\mathrm{H}_{2} \mathrm{O}\right)$ & $\begin{array}{l}\text { Exch. } \mathbf{K}^{+} \\
(\operatorname{cmol}(+) / \mathbf{k g})\end{array}$ & $\begin{array}{l}\text { Exch. } \mathrm{Ca}^{2+} \\
(\mathrm{cmol}(+) / \mathrm{kg})\end{array}$ & $\begin{array}{l}\text { Exch. } \mathrm{Mg}^{2+} \\
(\operatorname{cmol}(+) / \mathbf{k g})\end{array}$ & $\begin{array}{l}\text { Exch/Acidity } \\
(\mathrm{cmol}(+) / \mathrm{kg})\end{array}$ & $\begin{array}{l}\text { CEC } \\
(\mathrm{cmol}(+) / \mathbf{k g})\end{array}$ & $\mathrm{OC} \%$ \\
\hline 0 & 5.23 & $1.69^{\mathrm{b}}$ & $1.29^{\mathrm{b}}$ & $1.45^{\mathrm{b}}$ & $0.52^{\mathrm{c}}$ & 13.85 & 3.05 \\
\hline 23 & 5.35 & $1.84^{\mathrm{b}}$ & $1.26^{\mathrm{b}}$ & $1.58^{\mathrm{b}}$ & $0.65^{\mathrm{b}}$ & 14.06 & 3.09 \\
\hline 46 & 5.41 & $2.27^{\mathrm{a}}$ & $1.36^{\mathrm{a}}$ & $1.69^{\mathrm{a}}$ & $0.72^{\mathrm{a}}$ & 14.86 & 3.27 \\
\hline 69 & 5.38 & $2.51^{\mathrm{a}}$ & $1.45^{\mathrm{a}}$ & $1.83^{\mathrm{a}}$ & $0.76^{\mathrm{a}}$ & 15.12 & 3.33 \\
\hline $\operatorname{LSD}(5 \%)$ & ns & 0.26 & 0.12 & 0.19 & 0.08 & ns & ns \\
\hline $\mathrm{CV}(\%)$ & 3.71 & 7.33 & 9.11 & 6.79 & 7.13 & 8.87 & 2.73 \\
\hline
\end{tabular}

$\mathrm{DF}=$ degree of freedom; Exch. $\mathrm{K}=$ Exchangeable Potassium; Exch. Ca = Exchangeable Calcium; Exch. Mg= Exchangeable Magnesium; Exch. Acidity = Exchangeable Acidity; $\mathrm{CEC}=$ Cation exchange capacity; $\mathrm{ns}=$ non-significant; ${ }^{*}$ Significant $(\mathrm{P}<0.05) ; * *$ highly significant $(\mathrm{p}<0.01)$ difference.

\subsection{Effect of P Fertilization Rates and Its Placement Methods on Selected Soil Chemical Properties After Harvest}

The soil $\mathrm{pH}$ was not significantly $(\mathrm{P}>0.05)$ affected by both interaction of $\mathrm{P}$ fertilizer application rates, its different methods of $\mathrm{P}$ fertilizer placement. The soil reaction $(\mathrm{pH})$ after harvest was decreased under all treatments when compared to the initial soil pH 5.48 (Table 1). Application of $\mathrm{N}$ fertilizers adds hydrogen ions to the soil, hereafter, great acidity. According, to [66]. Fall in the soil $\mathrm{pH}$ after harvest indicating an increase in soil acidity, with high $\mathrm{N}$ chemical fertilizer. These results were also in link with finding of [67] who reported there was non-significant change in the $\mathrm{pH}$ of the soils in a number of treatments with different doses of inorganic fertilizers and organic amendments. Also, soil organic carbon non-significant $(\mathrm{P}>0.05)$ influenced by main effect of $\mathrm{P}$ fertilizer rates, its placement methods and interaction between the main effect of $\mathrm{P}$ fertilizer and its placement methods (Table 15). But, comparison from initial (2.73) organic carbon after harvesting the result show as fertilizer rate increase the organic carbon also increases. Based on this consideration, low content of organic carbon was obtained at control $(3.05 \%)$ while the increments result shows on the $\mathrm{P}$ fertilizer rate $3.05-3.33 \%$ of organic carbon determined (Table 15). There were non-statistically significant differences between the soil organic carbon due to $\mathrm{N}$ fertilization [68]. The values of organic carbon are measure of organic matter contents in the soil which is also determines soil fertility status. The organic matter helps to improve soil physical, chemical and biological properties such as soil structure, water and nutrients retention. Likewise, [69] also reported that increase in organic carbon of soil after harvest due to addition of higher biomass to soil. Cation Exchange Capacity of soil after harvest nonsignificant $(\mathrm{P}>0.05)$ influenced by both main effect of $\mathrm{P}$ fertilizer rate and its placement methods. The result show medium CEC of the soils could be attributed to the low organic matter contents in the soils (Table 15). This result agreement with [70] the increase of the CEC value is not strongly influenced by soil $\mathrm{pH}$ and total $\mathrm{N}$, being significantly influenced by $\mathrm{P}$ fertilizer content of soil. Exchangeable potassium after harvest highly significant $(\mathrm{P}<0.01)$ influenced by main effect of $\mathrm{P}$ fertilization rates, its placement methods and interaction between both main effect of $\mathrm{P}$ rates and its placement methods (Table 15). High levels of $P$ can reduce the availability of potassium, resulting in a deficiency in the crop. The soils in the study area had, very high exchangeable potassium, indicating that these soils have adequate levels of potassium for crop production. [71] reported the same level of exchangeable potassium in the soils at Bedele district. The mean exchangeable calcium cation in the soil was significant $(\mathrm{P}<0.05)$ influenced by $\mathrm{P}$ fertilization rate and interaction of main effects of $P$ fertilization rate and placement methods of $\mathrm{P}$ application, but, non-significant $(\mathrm{P}>0.05)$ by placement methods of $\mathrm{P}$ application. The result show after harvest calcium 
concentration ranged from 1.26 to $1.45 \mathrm{cmol}(+) \mathrm{kg}^{-1}$ these result shows very low (Table 15 ). The capability of plants to absorb calcium ions is then increased by application of soluble phosphate fertilizers. Application of ammonium phosphate increased the content of water soluble phosphate in a soil extract and the early uptake of $\mathrm{P}$ and calcium. These results agree with [38]. The reason behind why the calcium cation is very low was due to high rainfall of the study area the average mean rainfall is $1942 \mathrm{~mm}$ based on this the leaching of base cation high. Although, exchangeable magnesium in the soil tested ranged from 1.45 to $1.83 \mathrm{cmol}$ $(+) \mathrm{kg}^{-1}$ (Table 15) highly significant $(\mathrm{P}<0.01)$ difference both main effect of $\mathrm{P}$ fertilizer rate and placement methods of $\mathrm{P}$ application. The levels of exchangeable magnesium in all treatment from the study site was low $1.45 \mathrm{cmol}(+) \mathrm{kg}^{1}$ to medium 1.83. This results agreement with [38]. The low values of magnesium cation may be due to high rainfall and leaching the study area.

\subsection{Pearson Correlation Within Agronomic and Yield Parameters}

A simple correlation analysis was done to consider the association of different agronomic parameters of the maize crop. Both positive and negative associations between the parameters have been observed (Table 16). These values showed the magnitude and direction of the associations and relationships between agronomic parameters. For illustration, among the agronomic and yield components of maize grain yield was directly and significantly $(\mathrm{P}<0.05)$ positively correlated with thousand grain weight $(0.404)$ and highly significantly $(\mathrm{P}<0.01)$ positively correlated with plant height (0.725), total aboveground biomass (0.982), straw yield (0.889), and harvest index (0.791). Nevertheless, it was negatively and non-significantly $(\mathrm{P}>0.05)$ associated with days to tasseling (-0.200), and days to silking (-0.178). Whereas, it was negatively and highly significantly $(\mathrm{P}<0.01)$ associated with days to maturity $(-0.589)$. This indicates that increased days to tasseling, silking and maturity result in reduction of grain yield while total aboveground biomass, stalks yield and harvest index have resulted in increasing maize grain yield. Therefore, grain yield of maize was positively and significantly correlated with yield components [72-74]. Therefore, significant and positively correlated parameters moves in the same direction this means that as one variable increases, so does the other one while, significant and negatively correlated parameters moves in the inverse or opposite direction. In other words as one variable increases the other variable decreases [74]. The dry biomass yield was highly and positively correlated with plant height (0.693), harvest index (0.675), Stalks yield (0.960), total P (0.579) thousand seed weight $(0.81)$, but negatively correlated with days to tasseling $(-0.230)$, days to silking $(-0.209)$, and days to maturity $(-0.571)$ (Table 16). Moreover, positive and highly significant $(\mathrm{P}<0.01)$ correlation between grain yield with residual soil $\mathrm{P}(0.634)$, grain yield with total $\mathrm{P}$ in grain (0.616), grain yield with total $\mathrm{N}$ in the soil $(0.852)$, grain yield with total $\mathrm{N}$ in grain $(0.651)$ and grain yield with total $\mathrm{N}$ in stalks $(0.834)$ whereas, positive and significant $(\mathrm{P}<0.05)$ correlation between grain yield with total $\mathrm{P}$ in stover (0.403). Likewise, positive and highly significant $(\mathrm{P}<0.01)$ correlated between residual soil $\mathrm{P}$ with grain $\mathrm{P}$ uptake (0.617), residual soil $\mathrm{P}$ with stalk $\mathrm{P}$ uptake (0.505), residual soil $\mathrm{P}$ with total $\mathrm{P}(0.679)$ openly show their strong direct associations. The less typical direct relationship of Bray II residual soil P after harvest with $\mathrm{P}$ uptake and yield observed in this study may be due to the sufficient application of phosphate fertilizer rather than total of dissolved phosphorus in the soil from the initial soil reserve.

Table 16. Correlation Coefficients among different growth, yield and yield component parameters of maize crop.

\begin{tabular}{|c|c|c|c|c|c|c|c|c|c|c|c|c|c|c|c|c|}
\hline & TD & SD & MD & Pht & GY & BMY & SY & HI & TKW & TP & Res.P & TPG & TPS & TN & TNG & TNS \\
\hline TD & 1.000 & & & & & & & & & & & & & & & \\
\hline SD & $0.990 * *$ & 1.000 & & & & & & & & & & & & & & \\
\hline MD & $0.272 \mathrm{~ns}$ & $0.265 \mathrm{~ns}$ & 1.000 & & & & & & & & & & & & & \\
\hline Pht & $-0.064 n s$ & $-0.057 \mathrm{~ns}$ & $-0.554 * *$ & 1.000 & & & & & & & & & & & & \\
\hline GY & $-0.200 \mathrm{~ns}$ & $-0.178 \mathrm{~ns}$ & $-0.589 * *$ & $0.725 * *$ & 1.000 & & & & & & & & & & & \\
\hline BMY & $-0.230 \mathrm{~ns}$ & $-0.209 \mathrm{~ns}$ & $-0.571 * *$ & $0.693 * *$ & $0.982 * *$ & 1.000 & & & & & & & & & & \\
\hline $\mathrm{HI}$ & $-0.104 n s$ & $-0.089 \mathrm{~ns}$ & $-0.464 * *$ & $0.605 * *$ & $0.791 * *$ & $0.675 * *$ & $0.458 * *$ & 1.000 & & & & & & & & \\
\hline TKW & $-0.311 \mathrm{~ns}$ & $-0.300 \mathrm{~ns}$ & $-0.346^{*}$ & $0.310 \mathrm{~ns}$ & $0.404 *$ & $0.387 *$ & $0.336^{*}$ & $0.362 *$ & 1.000 & & & & & & & \\
\hline TP & $-0.337 *$ & $-0.331 *$ & $-0.577 * *$ & $0.562 * *$ & $0.573 * *$ & $0.579 * *$ & $0.550 * *$ & $0.412 *$ & $0.488 * *$ & 1.000 & & & & & & \\
\hline ResP & $-0.379 *$ & $-0.382 *$ & $-0.542 * *$ & $0.487 * *$ & $0.634 * *$ & $0.617 * *$ & $0.551 * *$ & $0.608 * *$ & $0.510 * *$ & $0.679 * *$ & 1.000 & & & & & \\
\hline TPG & $-0.257 \mathrm{~ns}$ & $-0.253 \mathrm{~ns}$ & $-0.459 * *$ & $0.536 * *$ & $0.616^{* *}$ & $0.648 * *$ & $0.650 * *$ & $0.359 *$ & $0.377 *$ & $0.778 * *$ & $0.617 * *$ & 1.000 & & & & \\
\hline TPS & $-0.309 \mathrm{~ns}$ & $-0.298 \mathrm{~ns}$ & $-0.344^{*}$ & $0.307 \mathrm{~ns}$ & $0.403 *$ & $0.388 *$ & $0.339 *$ & $0.355^{*}$ & $1.000 * *$ & $0.485 * *$ & $0.505 * *$ & $0.378 *$ & 1.000 & & & \\
\hline $\mathrm{TN}$ & $-0.186 n s$ & $-0.170 \mathrm{~ns}$ & $-0.488 * *$ & $0.764 * *$ & $0.852 * *$ & $0.847 * *$ & $0.782 * *$ & $0.653 * *$ & $0.338 *$ & $0.511 * *$ & $0.542 * *$ & $0.630 * *$ & $0.335^{*}$ & 1.000 & & \\
\hline TNS & $-0.302 \mathrm{~ns}$ & $-0.295 \mathrm{~ns}$ & $-0.609 * *$ & $0.689 * *$ & $0.834 * *$ & $0.812 * *$ & $0.726^{* *}$ & $0.670 * *$ & $0.451 * *$ & $0.721 * *$ & $0.736^{* *}$ & $0.785 * *$ & $0.451 *$ & $0.721 *$ & $0.557 *$ & 1.000 \\
\hline
\end{tabular}

$*=$ Significant at $\mathrm{P}<0.05 ; * *=$ Significant at $\mathrm{P}<0.01$; ns=non-significant; $\mathrm{TD}=$ Days to tasseling; $\mathrm{SD}=\mathrm{Days}$ to silking; $\mathrm{MD}=\mathrm{Days}$ to $\mathrm{maturity}$; $\mathrm{Pht}=\mathrm{plant}$ height; GY=grain yield; BMY = Biomass yield; $\mathrm{SY}=$ Stalks yield; $\mathrm{HI}=$ Harvest index; $\mathrm{TKW}=\mathrm{Thousand}$ kernel weight; $\mathrm{TP}=\mathrm{Total}$ phosphorus; Res.P = Residual phosphorus; $\mathrm{TPG}=$ Total phosphorus in grain; $\mathrm{TPS}=$ Total phosphorus in Stalks; $\mathrm{TN}=$ Total nitrogen; $\mathrm{TNG}=\mathrm{Total}$ nitrogen in grain; $\mathrm{TNS}=\mathrm{T}$ otal nitrogen in Stalks. 


\subsection{Economic Partial Budget Analysis}

The partial budget analysis of the treatments was done considering all variable costs and all benefits (grain yield). Accordingly, the least total variable cost (TVC) was recorded for the control treatment (without fertilizer), while the highest net benefit $\left(26977 \mathrm{ETBha}^{-1}\right)$ was obtained in response to application of $150 \mathrm{~kg}$ DAP ha ${ }^{-1}$ combined with $200 \mathrm{~kg}$ urea ha${ }^{1}$. The analysis of marginal rate of return (MRR), on the other hand, revealed that the rate of return per unit cost of production was highest for application of $150 \mathrm{~kg}$ DAP ha ${ }^{-1}$ with $200 \mathrm{~kg}$ urea $\mathrm{ha}^{-1}(\% \mathrm{MRR}=328.2)$. This showed that it would yield 3.28 Ethiopian Birr for every Birr invested. Thus, applications of $150 \mathrm{~kg}$ DAP ha ${ }^{-1}$ of combined with $200 \mathrm{~kg}$ urea ha ${ }^{-1}$ of is economically beneficial as compared to the other treatments, because the highest net benefit (NB) and marginal rate of return (MRR) was above the minimum level $(100 \%)$.

Table 17. Economic partial analysis of fertilizer rate on maize yield.

\begin{tabular}{|c|c|c|c|c|c|}
\hline Fertilizer $\left(\mathrm{Kgha}^{-1}\right)$ & Adjusted yield & Gross benefit & Total variable cost & Net benefit & Marginal rates of return $\%$ \\
\hline 0 & 1638 & 10647 & 0 & 10647 & \\
\hline 50 & 3724 & 24209 & 3787 & 20423 & 258.2 \\
\hline 100 & 3801 & 24707 & 4785 & 19922D & \\
\hline 150 & 5040 & 32760 & 5784 & 26977 & 328.2 \\
\hline
\end{tabular}

\section{Conclusions}

Sustaining soil fertility in serious cropping systems for greater yields of better quality can be achieved through optimum levels of fertilizer applications. In mark with this, research was assumed to investigate the effects of $P$ fertilizer rates and its placement methods of $\mathrm{P}$ application on residual soil $\mathrm{P}$, yield and agronomic parameters and $\mathrm{P}$ uptake of maize at Bedele district during the 2020 cropping season. Among the agronomic and yield parameters of maize; days to tasseling, and days to silking were not significantly $(\mathrm{P}>0.05)$ influenced by $\mathrm{P}$ fertilizer rates, placement methods of $\mathrm{P}$ fertilizer, and their interactions. The longest tasseling days (84.3day) was recorded from control treatment and the shortest tasseling days (81.8day) was recorded from the treatment receive $69 \mathrm{~kg} \mathrm{P}_{2} \mathrm{O}_{5} \mathrm{ha}^{-1}$. Also, longest days to silking (91.3day) recorded from control treatment and shortest days to silking (88.4day) were recorded from the treatment received $69 \mathrm{~kg} \mathrm{P}_{2} \mathrm{O}_{5} \mathrm{ha}^{-1}$ Concerning, $\mathrm{P}$ fertilizer rates and placement methods of $\mathrm{P}$ surface banding $\mathrm{P}$ to the sides of the seeds and application of $69 \mathrm{~kg} \mathrm{P}_{2} \mathrm{O}_{5} \mathrm{ha}^{-1}$ were the highest potential for grain yield, straw yield, harvest index and total above ground biomass yields. General conclusion, the highest soil total $\mathrm{N}$, total and residual $\mathrm{P}$ level increments were gotten by the use of surface banding $\mathrm{P}$ to the sides of the seeds and the lowest by using broadcasting $\mathrm{P}$ and seeds placement method of application. Similarly, surface banding $\mathrm{P}$ fertilizer to the sides of the seeds result shows that an advance of $\mathrm{N}$ and $\mathrm{P}$ contents and uptake by maize plant. Thus, applications of $150 \mathrm{~kg}$ DAP ha ${ }^{-1}$ of combined with $200 \mathrm{~kg}$ urea $\mathrm{ha}^{-1}$ of is economically beneficial as compared to the other treatments.

\section{Acknowledgements}

The authors grateful to the Oromia agricultural research institute their financial and logistic support. Next to Bedele agricultural research center for their technical and material support during soil sample analysis.

\section{References}

[1] Ethiopia agriculture and food security. USAID, 2021.

[2] Tittonell P., Corbeels M., Van Wijk, M., Vanlauwe, B. and Giller, K. 2008. Combining organic and mineral fertilizers for integrated soil fertility management in smallholder farming systems of Kenya: explorations using the crop-soil model FIELD. Agronomy Journal, 100: 1511-1526.

[3] Cobo J., Dercon G., \&Cadisch, G. 2010. Nutrient balances in African land use systems across different spatial scales: a review of approaches, challenges and progress. Agriculture, ecosystems \& environment (136): 1-15.

[4] Liu, M., Zhenrong Y., L. Yunhui, N. T. and Konijn, 2006. Fertilizer requirements for wheat and maize in China: The QUEFTS approach. Nutr. Cycling Agroecosyst. (74): 245-258.

[5] Waga Mazengia., 2011. Effects of Methods and Rates of Phosphorus Fertilizer Application and Planting Methods on Yield and Related Traits of Maize (Zea mays L.) on Soil of Hawassa Area. 2 (4).

[6] Marcie R. S., 2017. Impact of phosphorus placement on corn rooting dynamics under long-term strip-tillage. Kansas State University, Thesis.

[7] Tesfaye Balemi, Kefyalew Negisho, 2012. Management of soil phosphorus and plant adaptation mechanisms to phosphorus stress for sustainable crop production: a review. $J$ Soil Sci Plant Nutr 12 (3): 547-562. doi: 10.4067/S071895162012005000015.

[8] Mustonen PJ, Oelbermann M, Kass DCL, 2012. Using Tithonia diversifolia (Hemsl.) Gray, in a short fallow system to increase soil phosphorus avail- ability on a Costa Rican Andosol. J Agric Sci. doi: 10.5539/jas. 4 (2): 91.

[9] International Fertilizer Association (IFA), 2019. Production \& International Trade, Market Intelligence and Agriculture Services. Montreal (Canada) date 11-13 June 2019.

[10] CSA (Central Statistical Agency). 2014. Agricultural Sample Survey: report on area and production of major crops (private peasant holdings, Meher season). Addis Ababa. Statistical Bulletin. 
[11] Abera Wonde., Hussein Shimelis., Derera John., WorkuMosisa. and Laing Mark. 2013. Preferences and constraints of maize farmers in the development and adoption of improved varieties in the mid-altitude, sub-humid agroecology of Western Ethiopia. African Journal of Agricultural Research 8 (14). DOI: 10.5897/AJAR12.1972.

[12] Mesfin Abebe, 1980. Soil science development for agriculture in Ethiopia. Eth. J. Agr. Sci. 2 (2): 145-154.

[13] Hagos Brhane, Gebreslassie Hailemariam and Abrha Demoz, 2016. A Review on: Effect of Phosphorus Fertilizer on Crop Production in Ethiopia 6 (7).

[14] Brady, N. C. and Weil R. R., 2002. The Nature and Properties of Soils (13 ${ }^{\text {th }}$ ed). Pearson Education Ltd., USA. 960.

[15] Bedele development agricultural office, 2019.

[16] Mesfin Abebe, 1998. Nature and Management of Ethiopian Soils. Alemaya University of Agriculture, Ethiopia. 272.

[17] Dagne Chimdessa, 2019. Phosphorus calibration study under soil test based maize response in bedele district of oromia, west Ethiopia. Forest Res EngInt J. 3 (4): 154-158. DOI: 10.15406/freij.2019.03.00092.

[18] Bako agricultural research center CIMMYT, 2014.

[19] Buoyoucos, and G. H., 1951. Reclamation of the hydrometer for marking mechanical analysis of soil. Agronomy Journal (43): 434-438.

[20] Blake, G. R., Hartge, and K. H., 1986. Bulk density. In: Klute, A. (Ed.), Methods of Soil Analysis. Part 1. Physical and Mineralogical Methods, 2nd ed. Agron. Monogr. ASA-SSA, Madison, WI, (9): 363-375.

[21] Daniel H., 1980. Fundamentals of Soil Physics. A Subsidiary of Harcourt Brace Jovanovich, Publishers New York London Toronto Sydney San Francisco.

[22] Van Reeuwijk and L. P., 1992. Procedures for soil analysis. International soil reference and information center (ISRIC) Wageningen, The Netherlands. 23.

[23] Walkley, A., C. A. and Black, 1934. An examination of different methods for determining Soil organic matter and the proposed modification by the chromic acid titration method. Soil Sci. J. (37): 29-38.

[24] Houba, V. J. G., van der Lee J. J., I. Navozornsky and Walinga I., 1989. Soil and Plant Analysis Nertherland Wageningen Agricultural University, Netherlands 4-10.

[25] Isaak, R. A and Johanson W. C., 1976. Determination of total nitrogen in plant tissue. J. off. Ana.. Amer. chem. (58): 98-100.

[26] Rowell, and D. L., 1994. Soil science: Methods and applications. Addison Wesley Longman Limited. England. 350.

[27] Bray, H. R. and Kurtz L. T., 1945. Determination of organic and available forms of phosphorus in soils. Soil Science (9): 39-46.

[28] Brenner, I. B., A. E. Watson, Russell G. M. and Concalves M. 1980. A new approach to the determination of the major and minor constituents in silicate and phosphate rocks. Chemical Geology (28): 321-330.

[29] Olsen, S., and L. Sommers. 1982. Phosphorus. Pages 403-430 in A. Page, R. Miller, and D. Keeney, editors, Methods of Soil Analysis: Chemical and Microbiological Properties. $2 d$ edition. American Society of Agronomy, Madison, Wisconsin, USA.

[30] Tekalign Tadese. 1991. Soil, plant, water, fertilizer, animal manure and compost analysis. Working Document No. 13. International Livestock Research Center for Africa, Addis Ababa, Ethiopia.

[31] SAS Institute, Inc, 2012. The SAS System for Window Release 9.3; SAS Institute, Inc. Cary, NC, USA.

[32] CIMMYT. 1988. CIMMYT (International Centre for Maize and Wheat Improvement. From Agronomic Data to Farmer Recommendations: An Economics Training Manual, Completely revised edition, Mexico, 1988.

[33] Food and Agriculture Organization of the United Nations Rome, 2006.

[34] Gedefa Sori, Abdulmalik Mohammed and Dechasa Mengistu, 2018. Soil Fertility Assessment and Mapping of Bedele district of BunoBedele Zone, Oromia, Southwest Ethiopia.

[35] Wan, X. H., Huang, Z. Q., He, Z. M., Yu, Z. P., Wang, M. H., Davis, M. R., Yang, Y. S., 2015. Soil C:N ratio is the major determinant of soil microbial community structure in subtropical coniferous and broadleaf forest plantations.

[36] Manjula V. Nathan John Stecker A. and Yichang Sun, 2012. University Extension Division of Plant Sciences, College of Agriculture, Food and Natural Resources University of Missouri Revised 1/2012 Soil Testing A Guide for Conducting Soil Tests in Missouri.

[37] Rishid P., 2019. Understanding phosphorus forms and their cycling in the soil. ANR-2535.

[38] Landon, J. R., 1991. Booker Tropical Soil Manual: A hand book for soil survey and Agricultural Land Evaluation in the Tropics and Subtropics. Longman Scientific and Technical, Essex, New York. 474. OR John Wiley and Sons Inc., New York.

[39] Marton J., 2010. What Is Base Saturation in Soils? eHow Blog, Article. Retrieved 19/1/2011.

[40] Amanullah, H., Marwat, K. B., Shah, P., Maula, N. and Arifullah, S., 2009. Nitrogen levels and its time of application influence leaf area, height and biomass of maize planted at low and high density. Pakistan Journal of Botany, 41 (2): 761-768.

[41] Ayoola, O. T. and Makinde, E., 2009. Maize growth, yield and soil nutrient changes with $\mathrm{N}$-enriched organic fertilizers. African Journal of Food, Agriculture, Nutrition and Development, 9 (1): 580-592.

[42] Uwah, D. F. and Iwo, G. A., 2011. Effectiveness of organic mulch on the productivity of maize and weed growth. The Journal of Animal \& Plant Sciences, 2 (3): 525-530.

[43] Dagne Chimdessa, 2016. Blended Fertilizers Effects on Maize Yield and Yield Components of Western Oromia, Ethiopia. Agriculture, Forestry and Fisheries 5 (5); 151-162.

[44] Amanullah, Muhammad Z, Muhammad T, Khalid B, Amir Z, Farhatullah, ZahirSh, Amanullah J, Shad K, Muhammad Tariq, M. S, Zahid H and Hidyat-ur-rahman, 2010. Levels and time of phosphorus application Influence growth, dry matter partitioning And harvest index in maize. Pak. J. Bot., 42 (6): 4058.

[45] Sahoo, S. C. and Panda M., 2001. Effect of phosphorus and de-tasseling on yield of baby-corn. Indian J. Agric. Sci. (71): 21-22. 
[46] Tariq M, Rozina G, Fazal M, Fazal J, Zahid H, Nadia N, HamayoonKh, Nasiruddin and Hayatullah Kh, 2011. Effect of different phosphorus levels on the Yield and yield components of maize. Sarhad j. Agric. 27 (2).

[47] Fareed, M. K. 1996. Effect of varying fertilizer rate and plant stand density on growth and yield of spring maize. M.Sc. (Hons) Thesis, Deptt. ofAgron. Univ. of Agric. Faisalabad, Pakistan.

[48] Hussain, N., A. Z. Khan, H. Akbar and S. Akhtar. 2006. Growth factors and yield of maize as influenced by phosphorus and potash fertilization. Sarhad J. Agric. 22 (4): 579-583.

[49] Yihenew G. S., 2016. Response and Economic Feasibility of Maize (Zea mays L.) to P Fertilization in Acidic Alfisols of North-western Ethiopia. Selassie Environ Syst Res 5 (3). DOI 10.1186/s40068-016-0056-3.

[50] Manzoor Ahmad, Mohammad Jamal Khan and Dost Muhammad, 2013. Response of maize to different phosphorus levels under calcareous soil conditions. SarhadJ. Agric. 29 (1): 44.

[51] Khairul Alam Md., Richard Bell W., Nazmus Salahin, ShahabPathan, A. T. M. A. I. Mondol, M. J. Alam, M. H. Rashid, P. L. C. Paul, M. I. Hossain \& N. C. Shil, 2018. Banding of Fertilizer Improves Phosphorus Acquisition and Yield of Zero Tillage Maize by Concentrating Phosphorus in Surface Soil.

[52] Mustefa Redi, Wubayehu Gebremedhin, FitsumMerkeb, Mohamed Yimam, 2016. Critical Level of Extractable Phosphorus for Maize (Zea mays L.) At Metekel Zone, Northwestern Ethiopia.

[53] Mohsin M., Tian Y, Qingxia M, Waqas A, Sajid M, Xiaoli H and Zhaohui W, 2020. Changes in Phosphorus Fractions and Its Availability Status in Relation to Long Term P Fertilization in Loess Plateau of China.

[54] Abebaw Tadele Alem and Hirpa Legese, 2018. Effects of fertilizer rate (blended) and sowing methods on yield of bread wheat (triticumaestivum) and its economic profitability in western Ethiopia. 5 (7): 9.

[55] Muhammad T., Asefa T., H. Tajamol and Wasoya A. (2009). Yield response of wheat to Boron application. Pak. J. Life. soc. sci. 7 (1): 39-42.

[56] Yosef, T. S., 2013. Effect of Nitrogen and Phosphorus Fertilizer on spikelet Structure and yield in rice (Oryza sativa L). International Journal of Agriculture and Crop Sciences: 5 (11): 1204-1208.

[57] Mengel K., Kirkby E. A., 2001. Principles of Plant Nutrition, $5^{\text {th }}$ ed., Kluwer, Dordrecht, Boston, London, 453.

[58] EshetayehuTefera and Heluf Gebrekidan, 2017. Phosphorous use efficiency as affected by phosphorous placement methods and maize genotypes in ArsiNeggele, Ethiopia. Net Journal of Agricultural Science 5 (3): 94-104, ISSN: 2315-9766 Full Length Research Paper.

[59] EshetayehuTefera, 2001. Yield and Phosphorus Uptake of Maiz Varieties as Influenced By Phosphorus Placement Methods on Andosol of ArsiNeggale Area. A Thesis Submitted to SGS, AlemayaUniversty. 28-50.

[60] Endalkachew Kissi, Heluf Gebrekidan and AmanuelGorfu, 2006. Effects of Rates and Methods of Phosphorus Placement on Residual Soil P, Yield and P Up take of Wheat in Nitosols of Kulumsa Area, Arsi Zone M.Sc. Thesis, Alemaya University, Ethiopia.
[61] Eylachew Z., 1987. Study on the phosphorous status of different soil types of Charcher Highlands, South Eastern Ethiopia [Ph.D. Dissertation], University of Jestus Liebig, Giessen, Germany.

[62] Dubey, V., Patel, A., Shukla, A., Shukla, S. and Singh, S., 2012. Impact of continuous use of chemical fertilizer. International Journal of Engineering Research 3 (11): 3-16.

[63] Antonio P. Mallarino, Jose M. Bordoli, and Rogerio B., 1999. Phosphorus and Potassium Placement Effects on Early Growth and Nutrient Uptake of No-Till Corn and Relationships with Grain Yield. Published in Agron. J. (91): $37-45$.

[64] Fantaye Belay Marie and HintsaMeresaBerhe, 2020. Evaluation of Blended Fertilizer (NPSZnB) Rates on grain yield, nutrient uptake and economic feasibility of maize (Zea mays L.) in Kolla-Temben, Central zone of Tigrai, Ethiopia.

[65] Abdur R., Irfan A, Muhammad A., Sajjad H., Mubshar H., Shakeel A. and Fiaz A, 2018. Evaluating the Interactive Effects of Rates and Methods of Phosphorus Application on Wheat Productivity. Sci. Technol. Dev., 3 (1): 9.

[66] Quansah, G. W., 2010. Effect of Organic and Inorganic Fertilizers and their Combinations on the Growth and Yield of Maize in the Semi-Deciduous Forest Zone of Ghana (Msc Thesis). 147.

[67] Goyal, S., Chander, K., Mundra, M. C. and Kapoor, K. K., 1999. Influence of inorganic fertilizers and organic amendments on soil organic matter and soil microbialproperties under tropical conditions. Biology and Fertility of Soils, 29 (2): 196-200.

[68] Simansky, V., Kovacik, P. and Jonczak, J., 2017. The Effect of Different Doses of N Fertilization on the Parameters of Soil Organic Matter and Soil Sorption Complex. Journal of Ecological Engineering, 18 (3); 104-111.

[69] Negassa Wakene and Heluf G/Kidan, 2001. Assessment of Important Physicochemical Properties of Dystric Udalf (Dystric Nitosols) under different Management Systems in Boko Area, Western Ethiopia. MSc Thesis, Alemaya University, Ethiopia.

[70] Isidora R, Adina B, Sala F., Crista F., and AlinaLato, 2011. Mineral fertilization influence on soil $\mathrm{pH}$, cationic exchange capacity and nutrient content, Research Journal of Agricultural Science, 43 (3): 164.

[71] Ethiopian Soil Information System (EthioSIS), 2014. Towards improved fertilizer recommendations in Ethiopia - Nutrient indices for categorization of fertilizer blends from EthioSISworeda soil inventory data. Adissababa, Ethiopia.

[72] Yihenew, G., 2015. The effect of $\mathrm{N}$ fertilizer rates on agronomic parameters, yield components and yields of maize grown on Alfisols of North-western Ethiopia. Envi. SystResearc, 4 (1): 1-7.

[73] Habtamu, A., Heluf, G., Bobe, B. and Enyew, A., 2015. Effects of Organic and Inorganic Fertilizers on Yield and Yield Components of Maize at Wujiraba Watershed, Northwestern Highlands of Ethiopia. American J. of Plant Nutri. and Fertilization Technology, 5 (1): 1-15.

[74] Sisay Gurmu, 2018. Effect of blended NPS fertilizer and compost on growth and yield of quality protein maize (zea mays 1.) At Jimma, Southwestern Ethiopia. Thesis. 